\title{
Policy Interventions Promoting Sustainable Food- and Feed-Systems: A Delphi Study of Legume Production and Consumption
}

\author{
Bálint Balázs ${ }^{1, * \mathbb{D}}$, Eszter Kelemen ${ }^{1} \mathbb{D}$, Tiziana Centofanti ${ }^{1} \mathbb{D}$, Marta $W$. Vasconcelos ${ }^{2} \mathbb{D}$ and \\ Pietro P. M. Iannetta ${ }^{3}$ D \\ 1 Environmental Social Science Research Group (ESSRG), Impact Hub Budapest, Ferenciek Tere 2, \\ HU-1053 Budapest, Hungary; kelemen.eszter@essrg.hu (E.K.); tiziana.centofanti@gmail.com (T.C.) \\ 2 CBQF-Centro de Biotecnologia e Química Fina-Laboratório Associado, Universidade Católica Portuguesa, \\ Escola Superior de Biotecnologia, Rua Diogo Botelho 1327, 4169-005 Porto, Portugal; mvasconcelos@ucp.pt \\ 3 Ecological Sciences, The James Hutton Institute, Invergowrie, Dundee DD2 5DA, Scotland, UK; \\ Pete.Iannetta@hutton.ac.uk \\ * Correspondence: balazs.balint@essrg.hu
}

\section{check for} updates

Citation: Balázs, B.; Kelemen, E.; Centofanti, T.; Vasconcelos, M.W.; Iannetta, P.P.M. Policy Interventions Promoting Sustainable Food- and Feed-Systems: A Delphi Study of Legume Production and Consumption. Sustainability 2021, 13, 7597. https://doi.org/10.3390/ su13147597

Academic Editors: Adanella Rossi, Anna Irene De Luca and Giaime Berti

Received: 26 March 2021

Accepted: 30 June 2021

Published: 7 July 2021

Publisher's Note: MDPI stays neutral with regard to jurisdictional claims in published maps and institutional affiliations.

Copyright: (c) 2021 by the authors. Licensee MDPI, Basel, Switzerland. This article is an open access article distributed under the terms and conditions of the Creative Commons Attribution (CC BY) license (https:// creativecommons.org/licenses/by/ $4.0 /)$.

\begin{abstract}
The food- and feed-value systems in the European Union are not protein self-sufficient. Despite the potential of legume-supported production systems to reduce the externalities caused by current cultivation practices (excessive use of $\mathrm{N}$ fertilizer) and improve the sustainability of the arable cropping systems and the quality of human diets, sufficient production of high-protein legume grains in Europe has not been achieved due to multiple barriers. Identifying the barriers to the production and consumption of legumes is the first step in realizing new pathways towards more sustainable food systems of which legumes are integral part. In this study, we engage stakeholders and decision-makers in a structured communication process, the Delphi method, to identify policy interventions leveraging barriers that hinder the production and consumption of legumes in the EU. This study is one of a kind and uses a systematic method to reach a common understanding of the policy incoherencies across sectors. Through this method we identify policy interventions that may promote the production of legumes and the creation of legume-based products in the EU. Policies that encourage reduced use of inorganic $\mathrm{N}$ fertilizer represent an important step toward a shift in the increased cultivation of legumes. Relatedly, investment in R\&D, extension services, and knowledge transfer is necessary to support a smooth transition from the heavy use of synthetic $\mathrm{N}$ fertilizer in conventional agriculture. These policy interventions are discussed within current EU and national plant-protein strategies.
\end{abstract}

Keywords: sustainable food systems; policy analysis; legumes

\section{Introduction}

Legume-supported value chains, from production to consumption, provide evidencebased advantages that include improved ecosystem functions and resource use efficiency, as well as farmed animal and human health provisions. Environmental co-benefits of legumes include reduced nitrate leaching, increased food sources for pollinators, a greater structural diversity of farmland, and improved soil fertility [1,2]. Despite the potential of legumes to improve the sustainability of arable cropping systems and enhance the quality of farmed animal and human diets, the production and consumption of legumes in Europe is low, and their demand as feed is high, which is the adaptation of a phenomenon termed "the legume paradox" [3].

Multiple barriers limit the production, processing, marketing, and consumption of legumes in Europe, which are caused by various forms of system lock-ins and capacity gaps that span multiple levels of the food system. These system lock-ins have been 
analyzed extensively, and the low production and consumption have been attributed to many factors, such as (a) insufficient understanding and appreciation of non-marketed products and services of legumes by farmers, (b) agri-environmental regulations and public or private payments that only partly address the negative externalities produced by market failure of crop specialization, (c) lower yields and yield instability of legumes causing low profitability compared to other major non-legume crops, (d) reduced access to sufficient and publicly-funded independent agricultural extension or advisory services skilled in legume-supported crop system management, (e) lack of capacities for aggregation and post-harvest storage and processing, and (f) limitations in the categorization of legumes (in wholesalers) [3-6].

Identifying the barriers to the production and consumption of legumes locally is the first step to creating new pathways towards realizing legume-supported food systems in practice and accomplishing their associated benefits, too. Policies that attempt to favor legume-supported value chains are often inconsistent, as they conflict with a complex set of social, structural, market, and behavioral factors and capacities that influence stakeholders' perceptions and decisions. Furthermore, policies to increase more sustainable legume-supported production are not allied with a single coherent sustainable-food policy, since the latter is lacking from the EU policy portfolio, and the food policy domain is scattered and disintegrated. Policies that impact legume-supported systems operate across multiple governance levels shaped by international, EU, national, and regional agreements. The result is a conflicting policy framework: Some seek to diminish the environmental footprint of agriculture; others incentivize the agri-business strategies that are not in line with sustainable food systems $[4,7,8]$ or healthy diets [7].

To reduce reliance on imported protein and dependence on supply and market volatility, few countries in Europe (i.e., Germany, France, Denmark, Finland, and the Netherlands) have implemented national protein strategies to increase domestic protein production, and particularly for the large high-protein legume grains. Cultivated areas used to produce large-grain legumes have increased over the past 10 years because of numerous instruments based mainly on the foundation of financial incentives and specifically agricultural subsidies, most commonly derived from the most recent reform of the Common Agricultural Policy (CAP) in 2013 plus other national and regional funds. Income support payments to EU farmers are dependent on their "cross-compliance" with certain obligations. For example, the 2013 CAP reform determined 30\% of Pillar 1's "direct payments" as "greening" measures, including the option to cultivate grain legumes in Ecological Focus Areas (EFA) on at least $5 \%$ of each farm's arable land. Nearly $40 \%$ of the total EFA land area has been planted with nitrogen (N)-fixing crops. Out of the $12 \mathrm{EU}$ member states (MS) that produce soya, 10 made this crop eligible for planting in EFAs. This led to the EU having not just $5 \%$ of arable land in EFA, as regulations require, but $15 \%$. As such, the main driver for the increased production of high-protein legume grains in the EU is the subsidy for EFA without incentivizing those legumes with more sustainable value chains. Consequently, the introduction of a ban on the use of pesticides for N-fixing crops in the EFA is now slowing and reversing the positive progression of legume-protein production across the EU [8]. It may be argued that the policy goal should not be to invest public money in the production of legumes, but rather to create enabling conditions for the farming, processing, and consuming of legumes, which in turn can imply an increase in the sustainably managed agricultural area.

This leads us to question: How can the CAP, Supranational Protein Strategies [9], and the EU Farm to Fork Strategy within the European Green Deal [10] be integrated to address the "policy paradoxes" and deliver a more effective "policy toolbox" that is capable of sustaining increased grain legume production and consumption across Europe? Any improved suite of interventions should sustain legume grain production even when subsidies are removed and ensure sufficient market "pull" while overcoming any perceptions that reduced mineral $\mathrm{N}$ fertilizer use is linked to lower yields. Coherent policies in support of legume-supported cropped systems and the delivery of sustainable and healthy feed and 
food can be better designed when the stakeholders and decision-makers are engaged in the development of policies and governance frameworks [11,12].

Towards identifying this more resilient policy mix capable of overcoming the barriers hindering the production and consumption of legumes in the EU, we engaged a broad range of stakeholders and decision-makers using a systematic communication approach, the "Delphi method" [13,14], which facilitates the exchange of informed opinions on the legume paradox. In this process, we first reach a common understanding of the policy incoherencies across sectors and focus efforts towards identifying the suite of policy recommendations that may realize sustainable legume-supported food and feed systems more effectively across the value chain from production to consumption.

\section{Materials and Methods}

\subsection{The Delphi Method}

Expert-based future methods systematically investigate and develop policies regarding complex problems via the stimulation and informing of public dialogues. Policymakers can benefit from such strategic foresight in three main ways, according to the Organisation for Economic Co-operation and Development (OECD): (1) better anticipation, to identify and prepare sooner for new opportunities and challenges that could emerge in the future; (2) policy innovation, to spur new thinking about the best policies to address these opportunities and challenges; and (3) futureproofing, to stress-test existing or proposed strategies against a range of future scenarios. It is helpful especially in times of uncertainty when multiple future possibilities emerge, and the predictive capacities are limited [15].

Several other foresight methods are used in food policy and governance studies to create pathways to sustainability transformations. Delphi studies are often implemented in multimethod settings, in combination with multiple other foresight methods, such as horizon scanning, road mapping, visioning, multi-criteria analysis, stakeholder mapping, scenarios, participatory planning, back-casting, and serious gaming [16]. Foresight for food system transformations often requires multi-actor settings. Based on insights from the four case studies of the TRANSMANGO project, Hebinck et al. [17] argued that such collaborative spaces are prefigurative. That is, such foresight initiatives not only conceptualize, but even initiate transformative change by conceptualizing the needed change, creating new actor networks, and generating high-chance implementation strategies. In another setting, several pathways towards a sustainable food system in Kyoto in Japan have been designed by applying the combination of visioning, back-casting, and simulation games that altogether stimulate learning about new food-system practices [18]. In addition, new modes of governance, components, and resources for degrowth (moving away from implementation models that place economic growth as a central tenant of sustainable development) for food systems have been explored, for example, by the Budapest City Lab via visioning workshops with the actors of the local food system [19].

Delphi as a semi-quantitative, interactive foresight method gained popularity over the last 20 years for deployment in multiple settings with aims that ranged from exploratory studies to policy recommendations, from anticipating possible futures to suggesting desirable ones [20]. Delphi is typically preferred when the skill and knowledge of individuals in a particular area or subject need to be mobilized via an expert panel around a specific policy problem(s). The "legume paradox" offered such a scenario and helped identify policy recommendations for legume-based food systems. The Delphi method, as developed by Rand Corporation futurologists Norman Dalkey and Olaf Helmer, is considered an expert (tacit and explicit) knowledge aggregation procedure that can help planners and decisionmakers inform pragmatic choices regarding possible futures [21]. The Delphi method was devised to "obtain the most reliable consensus of opinion from a group of experts by subjecting them to a series of in-depth questionnaires, interspersed with controlled-opinion feedback" (p. 458, [22]). Helmer further explained that, "Delphi inquiry is not an opinion poll relying on drawing a random sample from the 'population of experts'." Instead, once a set of experts has been selected (regardless of how), it provides a communication device 
for them, and uses the mechanism of the exercise as a filter to preserve the anonymity of responses (p. 19, [23]).

Through a structured future-oriented communication process, Delphi enables the integration of individual expert opinions into a shared worldview. It thus helps the exploration of a problem space without pushing for a quick compromise. The main benefit of Delphi, as Rikkonen et al. [24] contended, is that it enables relatively quick consensus for solution-seeking. Furthermore, it provides practical descriptions for future decisions, and it is in this sense that it can act as a decision-support tool. Delphi's structured process means that experts are invited into a communicative learning process that enables opinion formation via an anonymous space for feedback and dialogue. Thus, Delphi can reduce pressure on free interaction by dominant individuals or to conform to the majority view [25].

A particular type of Delphi explores and develops dialogues for policy development. The "policy Delphi," according to Rayens and Hahn [14], is a systematic method for obtaining, exchanging, and developing an informed opinion on a policy issue or any institutional problem — such as the legume paradox or puzzle [3], and the arguments around its possible solutions. Raynes and Hahn [14] further emphasized the consensus-seeking aspect of this process for or against policy issues, whereas de Loe [26] outlined that it creates opportunities for future policy decisions. Authors in the published literature differentiated four main types of policy Delphi. In an "Argumentative Delphi" [27], the outcomes are consensual, evidence-based arguments. Thus, Argumentative Delphi can help policymaking, as panel members are known to each other and researcher-facilitators directly generate debate about the conflicting points. In contrast, a "Disaggregative Delphi" [15] provides the clustering of diverse opinions, and researchers attempt to outline various scenarios. In a "Trend Modelling Delphi," experts assess current trends, whereas in a "Structural Modelling Delphi," they assess causal linkages to create a new conceptual models of the issues. In sum, the main advantages of the Delphi, according to Landeta [28], are as follows: Social dominance is avoided, as high-status advocates cannot shape opinions-therefore, a plurality of viewpoints emerge; feedback loops enable a learning journey for participants; and some mathematical-statistical methods can be used in aggregating opinions. The main challenges of a Delphi are subjectivity, as it often reflects the subjective views of the summarizing experts; confirmation bias, i.e., a tendency to select the arguments according to summarizing experts' preconceptions; and interest, since general researchers' interests might be overrepresented compared to other stakeholders [15,16,29].

We chose the eDelphi open-source software (Metodix Ltd, Helsinki, Finland) to send out invitations by email. To reach a balanced composition of the invited experts, beyond our previous professional contacts, stakeholders from regional Legume Innovation Network (LIN) workshops organized within the EU-funded H2020 project TRUE and corresponding authors from the relevant literature on legumes were invited to join the panel. Eighty experts representing various sectors such as research, policy, advocacy, food processing, seed supply/crop breeding, and agronomist/agricultural extension services agreed to participate. Thirty-three (Round 1) and 43 (Round 2) experts finally participated in the Delphi. We gathered basic demographics (gender, age, sector, and education) of the participant experts in Round 1 and 33 participants provided their data. Our panel participants were predominantly 35-65-year-old male researchers with a doctoral degree [30].

The primary goals of this Delphi study were to:

1. Enable contributions of opinions from a panel of geographically dispersed policy experts and stakeholders;

2. Reach a common understanding of the legume policy incoherencies across sectors; and

3. Help opinion formation to identify policy instruments to leverage barriers for legume production and consumption.

This Delphi was conducted in two rounds. Round 1 mainly focused on identifying the significant factors contributing to the relatively low production and consumption of 
legumes in Europe. Round 2 primarily focused on outlining the potential target areas of policy scenarios, where future actions could support legume production and consumption.

\subsubsection{Round 1}

In Round 1, participants were asked the following questions.

(a) What are the policy challenges to increase domestic legume production and consumption?

(b) Why are legume cultivation and consumption rates relatively low in Europe?

(c) Which policies would lead to more legumes in our food system?

(d) What are the most effective policy mixes to forge pathways towards legume-supported food and feed systems?

After this set of questions, participants were asked to assess 10 statements (Table 1) outlining different policy interventions, which were identified based on literature review, document analysis, and case studies as reported by Balázs et al. [31]. The assessment looked at two aspects: the probability that a specific policy intervention leads to changes in legume production and consumption, and the impact that a specific policy intervention could have on legume production and consumption. Probability was ranked from 1 to 5 , where $1=$ very low probability, $2=$ low probability, $3=$ moderate probability, $4=$ high probability, and $5=$ very high probability. Impact was ranked from 1 to 5 on the same $1=$ very low to $5=$ very high impact scale. Participants had the option of including comments after each statement to explain the reasons for their assessment. After submitting their assessments and comments, other participants' responses were made visible so that the participant could choose to modify their answers if needed. It must be noted that various participants rated the impact only against legume production and not consumption, because for some participants (about 15\%), these two aspects should have been assessed separately.

Table 1. Description of statements outlining different policy interventions that affect legume production and consumption in Europe. The codes that identify each intervention were used in Figures 1 and 2.

\begin{tabular}{|c|c|}
\hline Statement Number and Code & Statement Description \\
\hline $1(\mathrm{~T})$ & $\begin{array}{l}\text { Changing international trade agreements would reduce the EU's } \\
\text { dependency on non-taxable soybean imports. }\end{array}$ \\
\hline $2(\mathrm{CI})$ & Agricultural incentives within the CAP support cultivation of legumes. \\
\hline $3(\mathrm{CG})$ & $\begin{array}{l}\text { Green direct payments of the CAP foster the transition to sustainable } \\
\text { food and feed systems. }\end{array}$ \\
\hline 4 (PS) & $\begin{array}{l}\text { Policies supporting legume production and consumption increase } \\
\text { industrialized livestock production as well. }\end{array}$ \\
\hline 5 (IRD) & $\begin{array}{l}\text { Investments in agri-food and -feed research and knowledge transfer } \\
\text { increase the competitiveness of protein crops and legume-supported food } \\
\text { products. }\end{array}$ \\
\hline $6(\mathrm{NFU})$ & $\begin{array}{l}\text { Preventing the use of inorganic } \mathrm{N} \text { fertilizers creates room for more } \\
\text { legume production. }\end{array}$ \\
\hline $7(\mathrm{CCP})$ & $\begin{array}{l}\text { Climate change policies may influence the reduction of meat production } \\
\text { and consumption; they also increase legume cropping and decrease the } \\
\text { use of inorganic fertilizer. }\end{array}$ \\
\hline $8(\mathrm{DH})$ & $\begin{array}{l}\text { Nutrition, diet, and health policies and public campaigns that promote } \\
\text { the inclusion of legumes in the human diet make legumes more visible } \\
\text { and increase imports for consumption. }\end{array}$ \\
\hline 9 (PFP) & $\begin{array}{l}\text { Public food procurement strategies that focus on sustainability offer } \\
\text { healthier options in foodservice markets that trigger shifts towards } \\
\text { legume-supported diets. }\end{array}$ \\
\hline 10 (TD) & Providing transparency of market data boosts legume value chains. \\
\hline
\end{tabular}




\subsubsection{Round 2}

In Round 2, participants were asked to assess the impact of seven policy scenarios (that included different measures and instruments derived from Round 1) that could impact (1) legume production and consumption, and (2) the sustainability of EU agriculture. The seven policy scenarios were extracted from Round 1 as the most relevant interventions, ranging from broad policy changes to more specific and targeted measures and instruments. Impact was assessed on a 7-point scale, where $1=$ strongly not impactful, $2=$ not impactful, $3=$ somewhat not impactful, $4=$ neutral, $5=$ somewhat impactful, $6=$ impactful, and 7 = strongly impactful. Participants were given the option to add comments after assessing each policy scenario. After the individual assessment, they were asked to select three of the seven scenarios they considered the most important to forge pathways toward legume-supported sustainable food and feed systems in Europe. The seven proposed policy scenarios are defined below.

(1) Legal measures to reduce the use of synthetic $\mathrm{N}$ fertilizer use (i.e., allowances for farmers).

(2) Increased environmental, safety, and ethical standards for imported raw protein sources.

(3) Funds for public-private extension plus research and development (R\&D) services supporting legume-supported cropping systems.

(4) Support for investments in technology (including breeding and agrotechnology), storage, and processing.

(5) Climate measures related to food consumption e.g., tax on meat, ban on red meat.

(6) Dietary guidelines and healthcare recommendations on why and how to shift to a (more) plant-based diet.

(7) Elimination of the CAP.

In addition, participants were asked to answer the following questions.

(1) How fast do you expect the proposed policy instruments to be implemented?

(2) Is it an incremental policy change, or rather a radical shift in policy that could lead to the implementation of the policy instruments you envisaged?

(3) What could be the role of various institutions (public and state institutions, large and small business, and bottom-up civic initiatives) to induce policy change?

\subsection{Data Analysis}

Data were analyzed using Gretl [31] and QDA miner 4 lite (Provalis Research, Montreal, QC, Canada). Descriptive statistical analyses were undertaken that included measures of means, medians, and quartile and interquartile ranges. This provided a first indication of the consensus or disagreement amongst participants. The greater the interquartile range, the greater the degree of dispersion from the central point of the trend in the group's response (median). Narrative answers (the textual comments) were coded using 40 in vivo codes in the first round and 51 in vivo codes in the second round. In vivo codes in the first round were grouped into six categories and mapped into a basic mental model showing logical links between the different categories. The six categories were enriched, cross-checked, and refined in the second round (see Appendices A and B for a detailed explanation). The six categories that finally emerged were (1) economics, (2) social, (3) environmental, (4) policies, (5) technology, and (6) farming.

In the economics category we had one sub-category ("economic/business") that included two codes (trade and marketing). Other codes included in the economics category were incentives, competition, value chain, demand, investment, and costs. In "social" there were nine codes: cultural barriers, tradition, values, preferences, complexity, health, consumption, education, and activism.

In the environmental category the six codes were sustainability, carbon sequestration, biodiversity, externalities, integrated/diversified farming, and greening measures; it 
also included one sub-category ("environmental/externalities"), which consisted of the following codes: climate change, pollution, fertilizer, and pesticides.

In the policies category, there were six codes and one sub-category with three codes. The six codes were subsidies, policy reforms, bans, regulatory policies, inertia, and supportive. The three codes for the sub-category "policies/bottlenecks" were systems lock-ins, risks, and bottlenecks.

In the technology/innovation category the five codes were processing, agricultural extension services, research, breeding, innovation, and knowledge. In the farming category, there were eight codes: production, crops/arable area, meat/dairy, smallholder/small scale, nutrition, good agricultural practices, rotations, and pest resistance. The codes were used to categorize the text of the comments and to quantify the codes that occurred most often in the comments for each scenario in Round 2.

\section{Results}

\subsection{Round 1}

Three policy interventions were ranked as most impactful and probable: (1) investments in research, development, and knowledge transfer (IRD); (2) restrictions on synthetic $\mathrm{N}$ fertilizer use (NFU); and (3) nutrition, diet, and health policies (DH). The results of the impact and probability assessment of all 10 statements are shown in Figures 1 and 2, and the qualitative analysis summary is shown in Figure 3.

The impact mean value of these policy interventions was around level 4, and IRD received lower values than NFU and DH (Figure 1) because there was doubt whether R\&D alone could increase the production and consumption of legumes, but the probability that this measure would occur received higher consensus (Figure 2). Outliers represented extreme positive or negative visions that this (IRD) measure alone could either solve the problem, or that it would not be possible to modify the system at this point since it is locked in.

The probability that NFU would lead to change was less clear, as the score values were widespread and ranged from 1 to 5 (Figure 2), indicating that the participants had contrasting views. Some participants voiced the fear that such a measure could negatively affect the entire agricultural sector, in particular cereal production, thus triggering an abandonment of farming altogether. As reported in the comments by some of the participants, this policy intervention is likely to produce a drastic change towards higher legume production, but the success of it depends on how to make such a shift. Nutrition, diet, and health policies $(\mathrm{DH})$ were rated higher. Still, such policies' impact is dependent on other policies that support innovation in food technology and incentivize short value chains. Participants pointed out that raising awareness of the benefits associated with legumes is a slow process, and the strategic design of such campaigns is key to the success of these interventions.

Policy interventions related to climate change (CCP), CAP greening (CG), CAP agricultural incentives (CI), and public food procurement (PFP) were considered of medium impact and probability, receiving values between 3 and 4 (Figures 1 and 2). Participants were in consensus about the high probability (Figure 2) that CAP-related policy interventions (CI and CG measures) would change legume consumption and production; however, the impact of these measures was less certain (Figure 1), as conventional farmers may need to be supported to meet the greening criteria and the market opportunities required to sustain these policies. Climate change policies received less consensus for impact (values ranged from 2 to 4 , Figure 1) and probability (values ranged from 3 to 4 , Figure 2) because of political inertia for implementing these measures and their limited scale of application. Public food procurement (PFP) had a medium impact, and the probability that this measure may change legume consumption and production is dependent on the innovative potential of food technology and the possible future change in consumer preferences and traditions.

The policy interventions that received the lowest values were changes in international trade agreements (T), transparency of data (TD) (Figures 1 and 2), and policies supporting legume production and consumption (PS). Policies in support of legume production and consumption may not be relevant because increased production of legume crops in the EU 
may not be possible/competitive and any of these policies must also address sustainability in general. Change in trade agreements received low support from participants who warned about complex interrelations within a globalized market (closing the gap between imported soybean sets the price level for protein crops in the EU). TD was considered to have a low impact, probably because the data are already available, and it showed no influence, according to the participants.
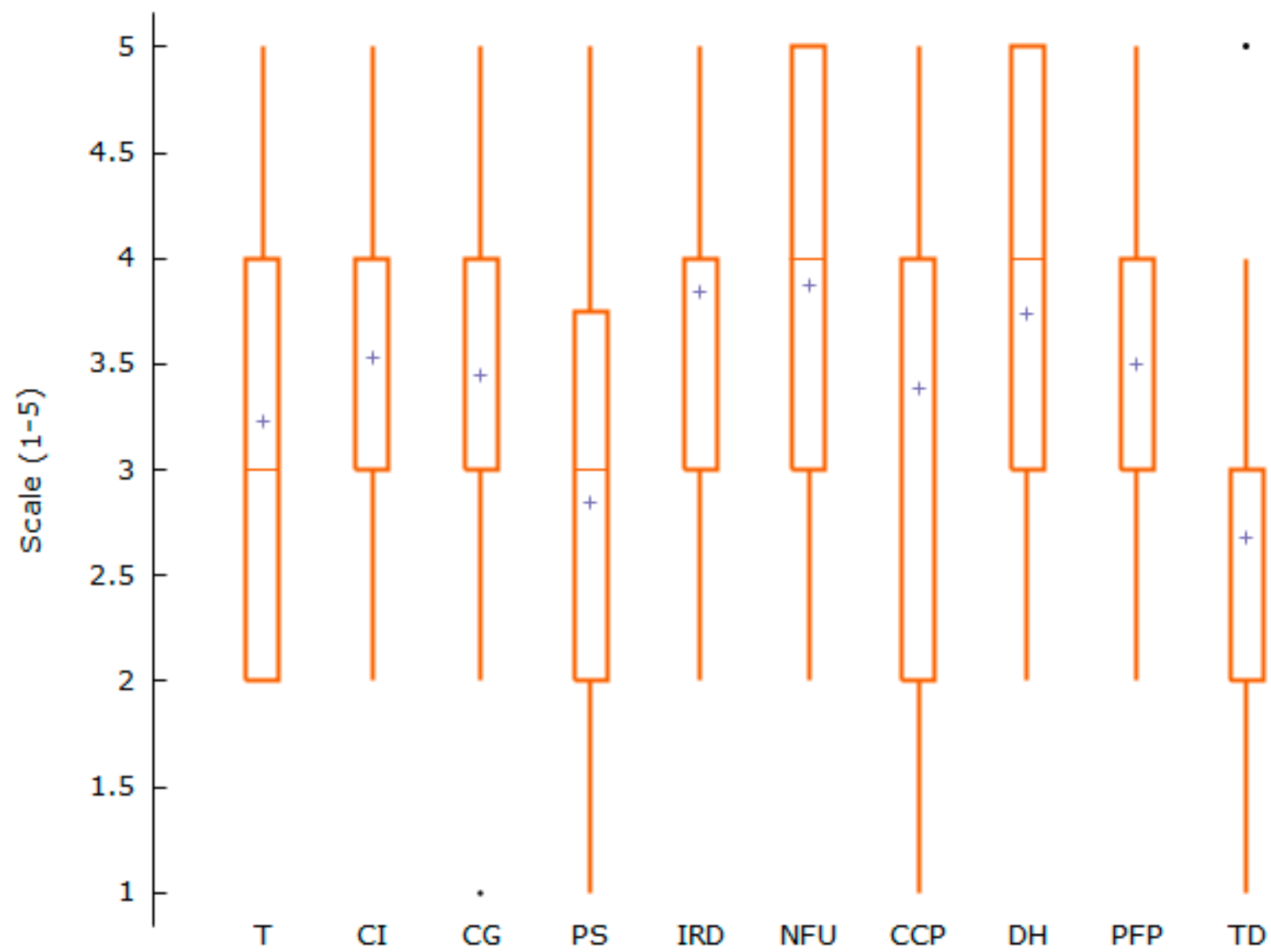

Figure 1. Boxplot assessing the impact of 10 policy interventions (described in Table 1), where $\mathrm{T}=$ trade policies; $\mathrm{CI}=\mathrm{CAP}$ incentives; $C G$ = CAP greening measures; PS = policy in support of legumes; IRD = investment in research and knowledge transfer; NFU = reduction in N fertilizer use; CCP = climate change policies; $\mathrm{DH}=$ nutrition, diet, and health policies; $\mathrm{PFP}$ = public food procurement; and TD = transparency of data. Impact was assessed on a 5-point scale, where $1=$ very low impact, 2 = low impact, 3 = moderate impact, $4=$ high impact, and $5=$ very high impact. The box displays the second and third quartiles; the line shows the median value, the cross is the mean, the whiskers display the interquartile range, and dots depict outliers. 


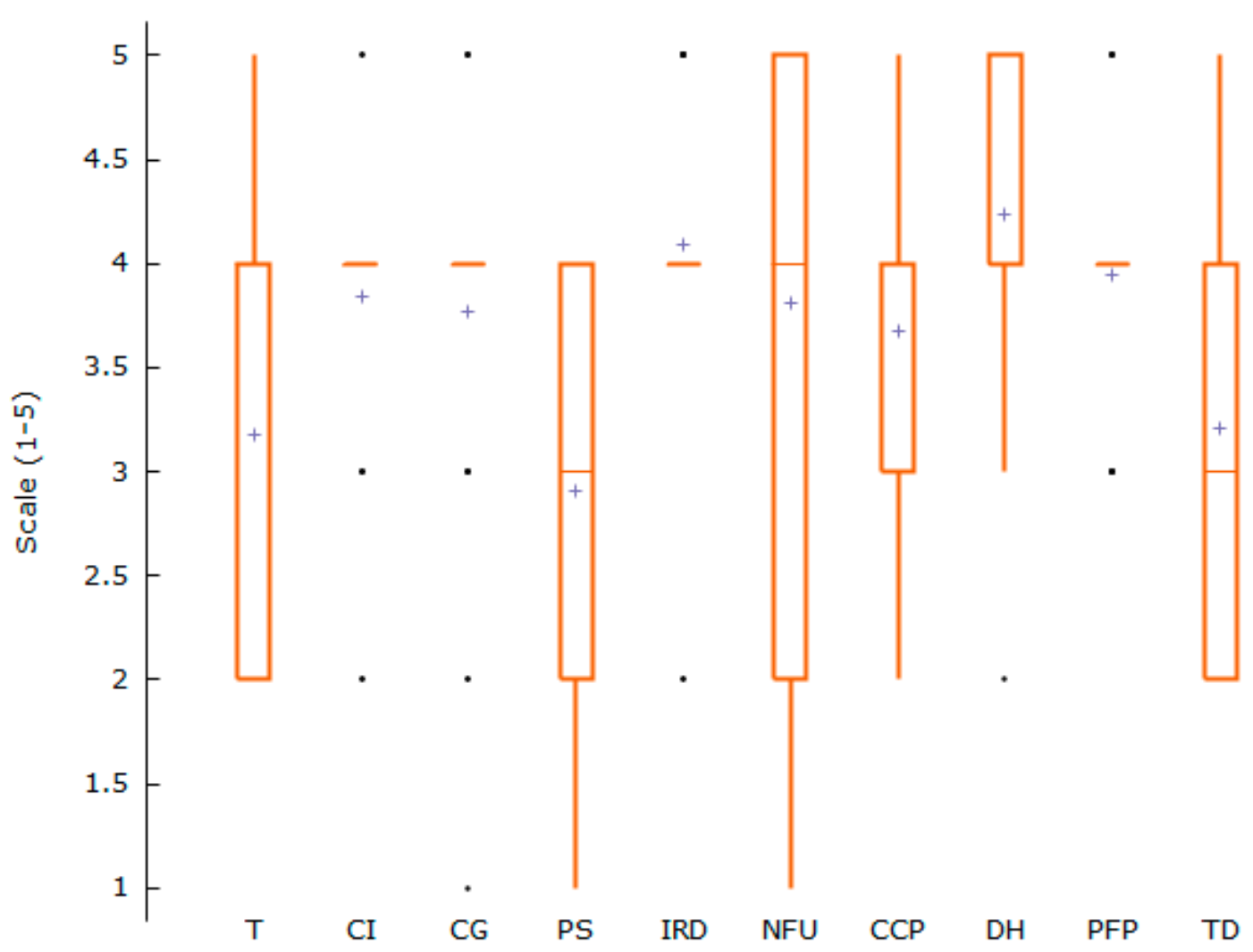

Figure 2. Boxplot assessing the probability of 10 policy interventions (described in Table 1), where $\mathrm{T}=$ trade policies; $\mathrm{CI}=\mathrm{CAP}$ incentives; CG = CAP greening measures; PS = policy in support of legumes; IRD = investment in research and knowledge transfer; NFU = reduction in N fertilizer use; $\mathrm{CCP}=$ climate change policies; $\mathrm{DH}=$ nutrition, diet, and health policies; PFP = public food procurement; and TD = transparency of data. Impact was based on a 5-point scale, where 1 = very low probability, $2=$ low probability, $3=$ moderate probability, $4=$ high probability, and $5=$ very high probability. The box displays the second and third quartiles, the line shows the median value, the cross is the mean, the whiskers display the interquartile range, and dots depict outliers.

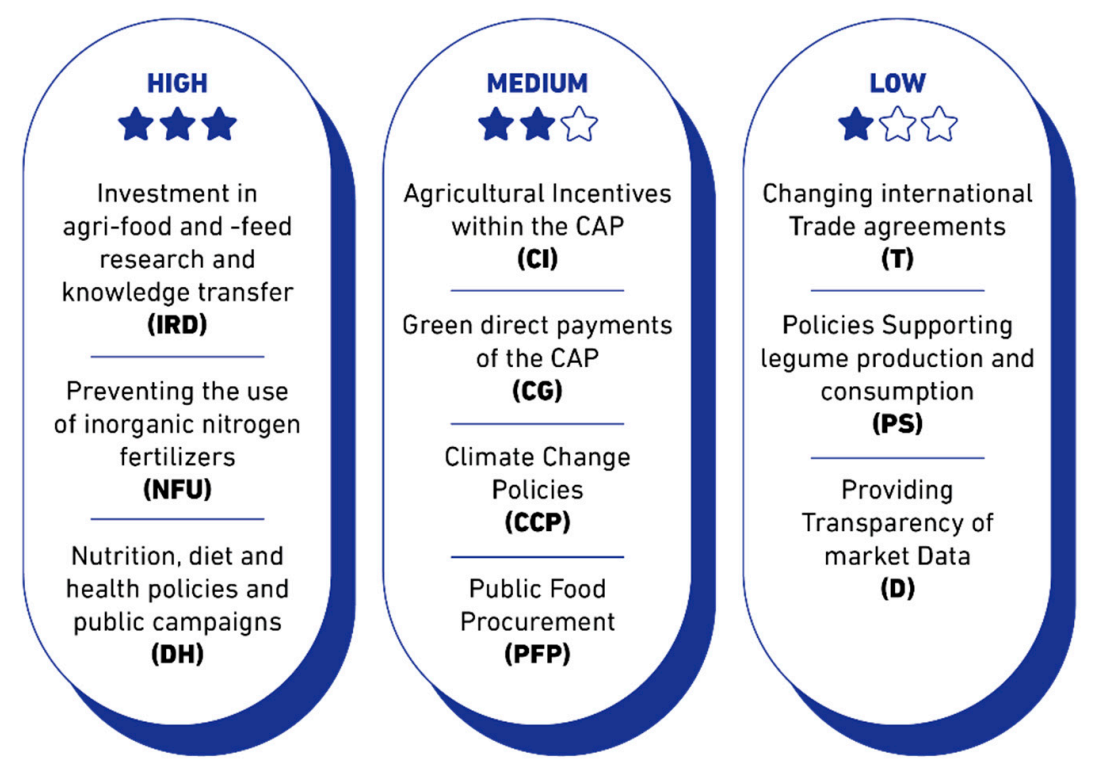

Figure 3. Summary description of participants' assessment (impact $\times$ probability, as shown in Figures 1 and 2). High = the policy has high potential to improve legume production and consumption; medium = the policy has medium potential to improve legume production and consumption; and low $=$ the policy has low potential to improve legume production and consumption. 


\subsection{Round 2}

Figure 4 shows the combined results of how respondents assessed the potential impact of the seven policy scenarios (Table 2) on the sustainability of EU agriculture and legume production and consumption. Participants rated the impact of eliminating the CAP as neutral or not impactful. Many commented that such a change is very drastic, and could result in a collapse in the EU agricultural sector. Few other participants (outliers) agreed that such an extreme measure is required to support the production and consumption of legumes, though the consequences may have negative social and economic repercussions if not properly implemented. The scenarios related to agricultural extension services, synthetic $\mathrm{N}$ fertilizer use, and R\&D were considered to have a medium impact (between 5 and 6) both on EU agriculture sustainability and on legume production and consumption. The outliers in the R\&D and agricultural extension services represent the vision that changes may require a structural reframing of the way agronomists and researchers are trained, because currently education in agricultural sciences is focused on cereals and oilseeds (and not on agroecological principles). Some respondents commented that reducing synthetic $\mathrm{N}$ fertilization may reduce yields to the extent that the whole agriculture sector would be impacted, causing an abandonment of farming altogether, as previously mentioned in Round 1. This impact-which has not occurred-was claimed before when the Water Framework Directive was implemented. Certainly, the impact of such a measure is stronger on legume consumption and production than on the sustainability of EU agriculture.

Table 2. Seven relevant policy interventions (left column) were identified in Round 1, and corresponding scenarios (right column) were discussed and ranked in Round 2.

Measure

Climate measures

“What If?" Scenarios

There will be public consensus to launch radical climate mitigation measures (e.g., requiring a significant decrease in the carbon footprint caused by food production), and collective political decisions are made in this direction.

Eliminate the CAP

Agricultural extension services

Regulating synthetic nitrogen fertilizer use

Nutrition, diet, and health policies

R\&D investments

Trade policy
A radical policy shift happens, and the EU stops all agricultural subsidies through the CAP.

Farm advisory and agricultural extension services become fully capable (both in terms of knowledge and human and financial resources) of supporting farmers and other actors along the value chain to implement new research outcomes at the farm level.

Stricter environmental and climate regulations are applied to crop and livestock production in Europe. The new measures combine legal restrictions on synthetic $\mathrm{N}$ use with a system of allowances for farmers.

Diet and health policies build on, and at the same time share with consumers, the best available knowledge on the nutritional value and the health and environmental impacts of different food sources.

Nutritional guidance on calorie intake is provided to consumers through various means (e.g., doctors, public food procurement rules, etc.).

Public R\&D investments are focused on new breeds, effective crop rotation schemes, new strategies to recycle $\mathrm{N}$ better, and novel options for the storage and processing of legumes.

Environmental, safety, and ethical standards are increased for imported raw protein sources (used either for feed or food) to level the playing field for homegrown legumes.

Interestingly, reducing synthetic $\mathrm{N}$ fertilization was preferred over others because it was considered the one with the highest probability of increasing legume production and consumption (Figure 5). Climate measures were rated positively on average (mean $=6$, 
Figure 4) though their range was broad, and so consensus was not apparent. Similarly, trade policies were considered to have medium and high impact on legume production and consumption, and less impact on agricultural sustainability. Scenarios of nutrition, diet, and health received the highest consensus for the impact on EU agriculture sustainability, with some outliers, and less consensus for legume production and consumption. An indepth analysis of the text and the reasons given by the participants for the assessment are provided below.

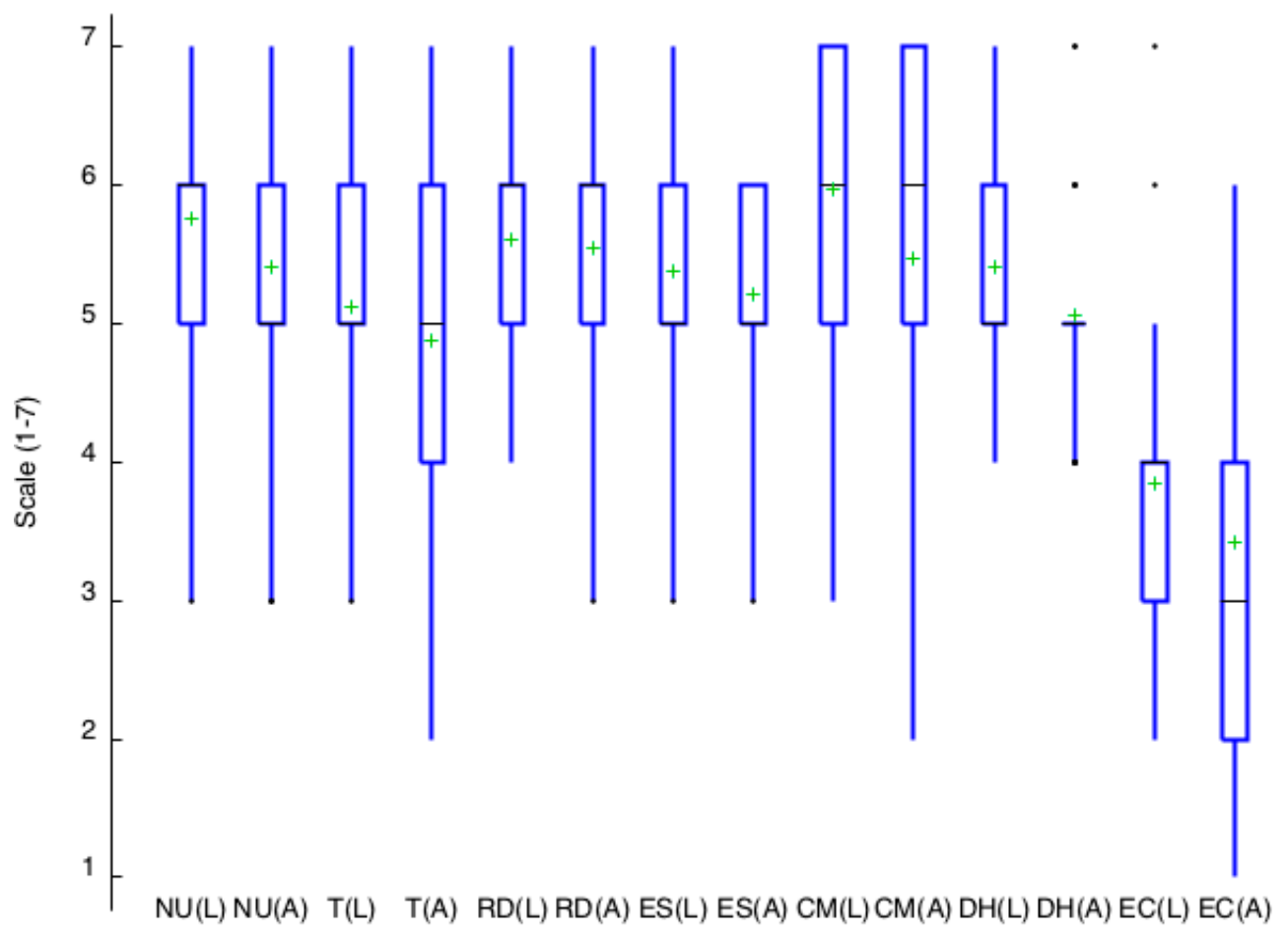

Figure 4. Boxplot of the impact assessment for the various policy scenarios described in Table 2, where NU = nitrogen fertilizer use; $\mathrm{T}$ = trade policies; $\mathrm{RD}=$ investment in research and development; $\mathrm{ES}=$ agricultural extension services; $\mathrm{CM}=$ climate measures; $\mathrm{DH}=$ nutrition, diet, and health; and EC = elimination of the CAP. Each policy scenario was evaluated for its impact on (L) legume production and consumption and (A) the sustainability of EU agriculture. Impact was based on a seven-point scale, where 1 = strongly not impactful, $2=$ not impactful, $3=$ somewhat not impactful, $4=$ neutral, $5=$ somewhat impactful, $6=$ impactful, and 7 = strongly impactful. Each boxplot displays the second and third quartiles, the line within each box shows the median value, the whiskers display the full data range, and dots depict outliers.

\section{Discussion of the Policy Scenarios}

Delphi for food policy transformation is becoming increasingly popular. For example, in 2015 an international panel of food policy experts assessed the effectiveness of good food environment policies via the Delphi study by Mahesh et al. [32]. Food prices and promotion were found to be the most valued policy domains with regards to impact on improving population nutrition. Interestingly, trade received the lowest weighting. As for specific policies, taxing unhealthy foods and promoting healthy food provision in schools were the most highly valued, whereas nutrient declarations on packaged foods and healthy food policies in private-sector workplaces received the lowest weightings. Tiberius et al. [33] explored the potential development of cultured meat by 2027. The Delphi study participants doubted that the challenges of mass production, production costs, and consumer acceptance would be overcome by 2027.

Considering climate change and its impacts, consumer perceptions, and continued research and development, environmentally sustainable food systems are inevitable. In an expert Delphi, Antonelli et al. [34] explored the trends, challenges, and policy options in the agri-food sector of the Mediterranean region over the short (to 2020) and the long 
(to 2030) terms by developing "pessimistic" versus "optimistic" scenarios. Similarly, the assessment of country-of-origin labeling policy mobilized 19 food policy experts from 13 countries in a consensus-seeking Delphi [35]. Based on expert knowledge, the multiplecountries-of-origin labels can give accurate information about the origin of food produced by two or more countries, avoiding misinformation for consumers. In the TRANSMANGO EU project, 45 international food policy experts participated in a Delphi to identify global drivers of the food system affecting EU food and nutrition security. According to MoraguesFaus et al. [36], there seems to be a broad consensus around the FAO definition of food and nutrition security (identifying it as access, availability, and sustainability). However, much less consensus could be recorded about the food system, which is understood in more dynamic terms, either as actor oriented (a small number of dominant agents' structure value chains), or systemic, where a mixture of stakeholders, flows, material devices, institutions, norms, beliefs, and activities constitute mixed determining factors. Note that only a few respondents referred to "intangible" dimensions of the food system in their definitions, such as governance, culture, environmental externalities, and knowledge. Allen et al. [37] proposed sustainable food system metrics specifically for the Mediterranean area and involved expert-agreed consensus in a Delphi survey regarding the indicator selection process. Frewer et al. [16] suggested exploratory workshops to refine Delphi questions and showed that beyond the relevance of the issue to the invited participant, response rates could be increased by leveraging personal networks. They also emphasized that policy uptake of the outputs of Delphi merits further research. Boylan et al. [38] explored the perceptions and role of the Australian policy actors on a healthy, sustainable, and safe food system in a Delphi survey. They recorded a critical consensus on the definition and essential elements of a cross-sectoral food and nutrition policy to meet today's environmental, health, social, and economic challenges.

Agri-food policy development could therefore benefit from soliciting expert opinion and consensus solution-seeking by utilizing a Delphi. Although consumer engagement in food and health policy development is rare, public discourse regarding policy options for healthy eating, or against non-communicable diet-related illness, is dominated by industry and government stakeholders. Haynes et al. [39] explored the consensus on obesity policy priorities of underrepresented stakeholders in the Australian context. In a three-round online policy Delphi, consumers, public health practitioners, and policymakers prioritized options to reduced obesity and its impacts. In a final face-to-face discussion group, participants explored stakeholder perceptions of the intrusiveness (ethical acceptability) of obesity policy options. Hung et al. [40] investigated the challenge of improving consumer motivation and interest in healthy eating by using nutrition labels (health claims and symbols). In their policy recommendations and communication guidelines they concluded that health claims with shorter and less complicated messages and health symbols with a visible endorsement were the most highly valued and therefore more efficient.

In essence, seeking food policy transformation via foresight methods such as Delphi are becoming increasingly favored, especially when it comes to critical consensus-solution seeking or assessments of food policy instruments' legitimacy or acceptability. Agri-food policy development for sustainable food systems can benefit from a Delphi by identifying the internal incoherencies and creating new policy discourses about options and priorities that are usually dominated by industry stakeholders. Below we discuss the suite of policy options and our recommendations that may realize sustainable legume-supported food and feed systems more effectively across the value chain, from production to consumption.

\subsection{Eliminate the CAP}

This measure was considered too drastic because a certain level of incentives or subsidies are considered essential to support farmers' income and the economic sustainability of EU agriculture. There is a fear that in the absence of the CAP, market forces would overcome commercial competitiveness of EU farms, causing negative social, economic, and environmental consequences, including the abandonment of farming, land concentration 
in the hands of very few, and environmentally negative land-use changes. In addition, productivity may not change because a few large-holder farmers will acquire most of the land, and small and medium-sized landholders will cease to be commercially profitable and therefore forced out of farming. This, in turn, would have a serious impact on the economic viability of EU agriculture, and the effect on legume production would be secondary (Figure 4). A few participants commented that elimination of the CAP may be beneficial (whiskers spread to level 6, Figure 4) after careful analysis of costs and benefits and examination of the consequences of such changes in countries where this has been already implemented (i.e., New Zealand, Canada, Australia).

We argue that a reflection on CAP's future and what it can do to increase home-grown legume production must encompass the planning and coordination of the full range of CAP tools that each MS implements in its territory. Obligations on environmental and climate action are strictly dependent on local conditions and, thus, on the strategic planning and implementation within each MS. One of the proposed tools of the future CAP (post-2021) is to implement obligations and incentives for farmers to ensure that crop rotation occurs and that the temporal period of those rotations is increased, which goes beyond simply encouraging crop diversification (i.e., increasing the number of crops in the rotation) [10,41]. Encouraging lengthier crop rotations could induce an increase in legume production as an integral component of a truly holistic cropped system, and not simply for subsidy payment (i.e., greening obligations). A key lesson derived from the EU supranational Plant Protein Strategy is that optimized delivery of the plan must be targeted to accommodate regional-level considerations, such as pedoclimatic, biogeographical, and socio-economic differences [42].

\subsection{Climate Measures}

Many participants concentrated their answers on the suggestion of banning or limiting meat consumption and production, and therefore the impact in this policy scenario varied in a wider range (from point 2 to point 7 ) than in the other scenarios (Figure 4). Their main argument against reducing meat production was that it may have a strong impact on the sustainability of farming systems through reduced availability of organic $\mathrm{N}$ (and carbon) sources, as well as the absence of grass-lays (and reduced pesticide use, amounts, and formulations) in rotations. However, the economy of many EU regions is dependent on meat production, particularly those with limited capacity for arable operations-since some participants argued that pastures are part of the landscape, and they provide ecological benefits (such as $C$ sequestration, biodiversity). Implementation of climate measures may cause a positive impact on both indicators if integrated farming is considered, where legumes are produced as feed and food in a low-input farming system that includes livestock as an integral part of the production unit [43]. Most participants thought that any reduction in livestock and meat production would cause a decrease in biodiversity and sustainability (Appendix C, Table A1). Potential arguments behind this opinion might be the negative biodiversity outcomes associated with the abandonment of traditional pastures, or the expected increase in land-use pressure associated with the production of meat-replacement options. According to several respondents, the decrease in biodiversity would be visible beyond the farmgate, too, as processing facilities for meat and dairy would need to be replaced, and innovation and investments would be required in new types of processing technologies for the development of plant-based products. The scenario of reducing meat production was favored only by some participants, whereas others assumed this to be currently too extreme due to political inertia and public uncertainty regarding the immediacy of the climate change risk. Reducing the dependency on plant protein imports (i.e., soybean) and / or decreasing the risks of potential protein insufficiency, mainly with respect to the animal feed requirement, is a main goal of the EC report on the development of plant proteins in the European Union, a report that does not discriminate legumes from other protein crops. 


\subsection{Regulating the Use of Inorganic N Fertilizers}

Overall, restrictions on mineral $\mathrm{N}$ fertilizer use can create a positive impact on the production of legumes, whereas the impact on consumption is less certain. Increased production of legumes requires the development of a set of best practices and crop rotation schemes that are more efficient (i.e., adapted to various pedoclimates to minimize crop inputs) (Appendix C, Table A1). This measure was considered too drastic by some participants, who feared that it may push many farmers out of business, especially conventional farmers.

The inclusion of $\mathrm{N}$-fixing plants such as legumes in the crop rotation or production system (grass mixes) is another management practice that replaces $\mathrm{N}$ fertilizer by using biological atmospheric $\mathrm{N}\left(\mathrm{N}_{2}\right)$ as a source and making it available to the plant. Environmental co-benefits include reduced nitrate leaching, increased food sources for pollinators, greater structural diversity of farmland, and improved soil fertility [44]. However, simply regulating $\mathrm{N}$ fertilizer use is not enough to make the shift towards increased legume production. Closing the nutrient cycle, i.e., encouraging a circular organic-N economy, at the local, regional, and national levels, including linking urban and rural nutrient cycles, would lead to a more sustainable use of natural resources. This type of approach is partly implemented in organic farming and food systems based on agroecological principles. As highlighted in the development process of the German National Protein Strategy, this return on investment, or risk, is delivered over the longer term, such as 5-8 years compared to a single year, for the immediate commercial rewards offered by market opportunities. As such, farmers need stronger incentives to de-risk this long-term undertaking and bridge any financial shortfall [42]. It is also necessary to integrate $\mathrm{N}$-fertilizer reductions with other interventions, including the breeding of new varieties (e.g., for pest resistance and higher yield), provision of independent agricultural extension services, more research and innovation, and investment in the processing capacities for legume-derived carbohydrates (i.e., fiber/starches and oils), as well as proteins to help add value and boost demand and consumption.

\subsection{Agricultural Extension Services}

Agricultural extension services, including farmer training and cooperative research, can have a strong and positive impact on the sustainability of EU agriculture and the potential increase in legume production and consumption (Figure 4). It was perceived that this provision would have a stronger impact on production than on consumption. Nevertheless, incentives and policies that support farmers, and other actors along the value chain, to increase legume cultivation may trigger increased demand for agricultural extension services by farmers. Currently, the EU area cultivated with legumes is very small (relative to cereals) and extension services and research agencies are not interested in developing training for agronomic support for a crop such as legumes, which can be considered marginal or underutilized (Appendix C, Table A1). Within the EU, the development of supranational protein strategies and their implementation via effective knowledge transfer is considered a pillar to realize rural areas' economic development. However, most of these strategies value legumes in a rather narrow way, mostly for their protein content, and consequently, they do not help actors along the value chain to capitalize on the multitude of benefits legumes provide for agri-food and -feed systems. Setting up producer organizations and cooperatives, and cooperation along the value chain, are additional strategies that may be adopted to decrease dependence on plant protein imports. The Farm Advisory System (FAS) is currently available to the MS, and this agency also works to ensure farmers' awareness of environmental co-benefits of long-term legume-supported crop rotations for plant protein provision.

Finally, increased funds for training, advisory, cooperation, and innovation in support of greater "fiscal literacy" were also seen as highly important: Such knowledge is very often the key to achieving both commercial profitability and environmental sustainability. 


\subsection{Nutrition, Diet, and Health Policies}

Knowledge regarding the health and nutrition benefits of legumes may be insufficient to trigger an increase in consumption. Existing preferences and cultural barriers (Appendix $C$, Table A1) may be a strong deterrent to the consumption of legumes, even if nutritional, environmental, and health benefits are high, but the effective marketing of novel, easy-to-cook, tasty, and environmentally beneficial plant-based products may effectively increase legume consumption [45].

Therefore, it is important to increase investment in $R \& D$ and processing technology to create a market for high-quality plant-based products. Participants believed that impact on production from the perspectives of nutrition, diet, and health would be minimal. Nevertheless, the impact on the sustainability of EU agriculture is expected to be moderate, and the consensus amongst participants on this was high, with only a low number of outliers (Figure 4 ).

The market for plant-based "meat" and "dairy" products is rapidly growing, and it is predicted to reach a global net of EUR 4.2 bn by 2020. Currently, Europe is the largest market for meat substitutes, with a 39\% global market share [46].

The EU plan on the development of plant proteins suggests that using demand-side policy tools, such as standardization, labeling, and public procurement, may create the necessary market pull for legume-based products and ultimately lead to lower dependence on feed protein imports.

\subsection{Investing in Research and Development (RED)}

$R \& D$ can have a strong impact on legume production and the sustainability of EU agriculture (Figure 4). Legume cultivation has many technical challenges-as reported by the participants - that need to be tackled through applied research. For example, developing more effective crop types such as new varieties with higher and more-stable yields, better pest resistance, short time to harvest, and that may also minimize $\mathrm{N}$ loss and optimize N-cycling in-field [19]. These measures could be coupled with other types of incentives (policy reforms) to stimulate legume cultivation (Appendix C Table A1).

An opportunity to encourage the breeding of grain legumes is to ensure farmers with a minimum level of profitability [47]. Besides financial incentives within a national protein strategy, adjustments could be directed towards improving support for decentralized capacities for breeding, storage/aggregation, processing (dehulling, milling, fractionation), and marketing of local and regional legume varieties.

\subsection{Reforming Trade Policies}

Some participants thought that imports would become very costly because of the barriers imposed with the predicted scenario presented in this study (Appendix C Table A1). There was a fear that this policy scenario would increase food prices, with social and economic consequences; hence, the impact on the sustainability of EU agriculture spanned from low to high (Figure 4). Some participants commented that EU homegrown legumes may not be necessarily more sustainable (from "cradle to grave" life cycle assessment) than those produced outside the EU.

This integrative policy scenario may increase the competitiveness of homegrown legumes, but success demands that this approach be complemented with other reforms in R\&D and innovations in production and processing, etc. To many participants, it was not clear that the EU would be able to replace imported legumes with homegrown production, as the current area cultivated with legumes and the scale of current imports do not support this vision.

\section{Summary: Forging Pathways towards a More Sustainable, Legume-Based Agriculture}

When participants were asked to rank the most impactful policy scenarios, regulating the use of synthetic $\mathrm{N}$ was the most highly ranked option (Figure 5). Elimination of the CAP was considered a very radical change, and most participants did not support it for 
reasons already explained above (Appendix C Table A1). A few participants commented that most of the scenarios may act negatively against other parts of the sector. Instead, they proposed to have a mix of "positive discrimination" measures in favor of legumes, such as "carbon credits" or an "environmental credit" system. The CAP should not be eliminated; instead, it can be reformed using a system of positive rewards for legume production. Currently, the EFA is the only positive support system in favor of legumes, and it has been ineffective, largely due to the associated ban on pesticide (and $\mathrm{N}$ fertilizer) use. Overall, participants preferred incremental changes because adaptation and preparation are needed when reforms are put in place. A radical change was deemed necessary by a small fraction of respondents $(<5 \%)$, whereas it was considered a potentially costly disruption by the majority.

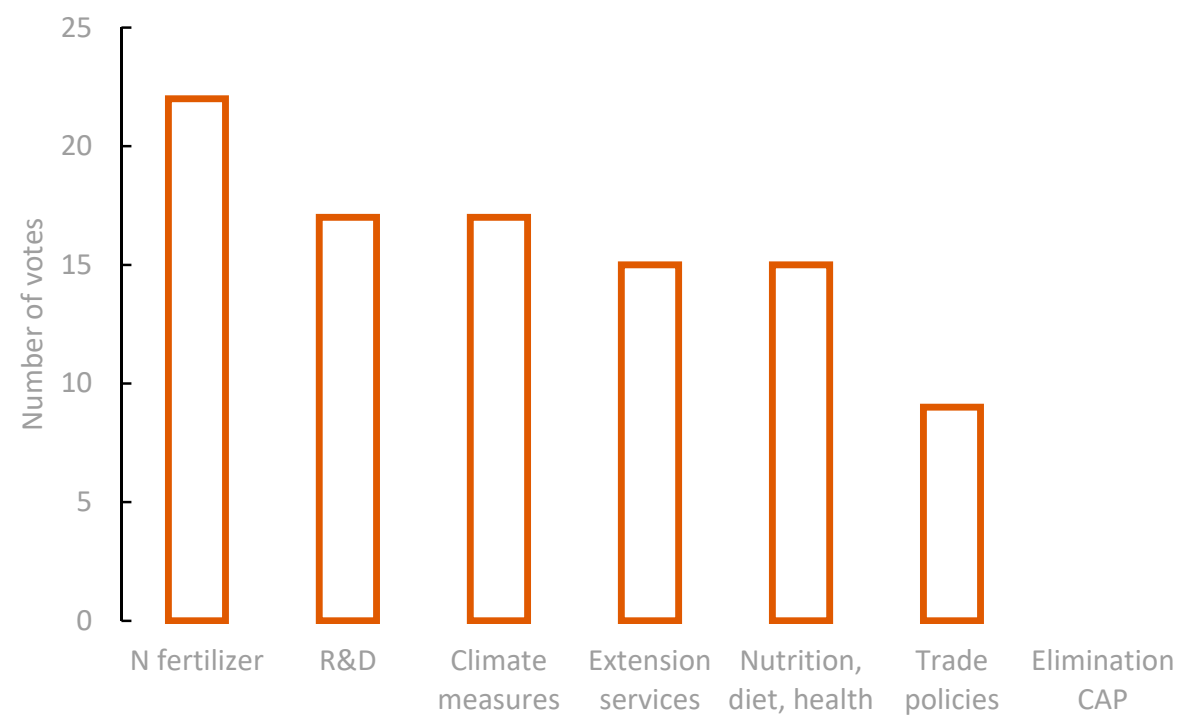

Figure 5. The number of votes given by the participants when asked to choose the three most important policy scenarios that could forge pathways towards legume-supported, sustainable food and feed systems in Europe.

The role of the institutions capable of affecting change were identified as businesses, public and state institutions, and bottom-up civic initiatives. Innovation, processing capacities, and breeding were associated with high responsibility for the private sector (business), whereas knowledge, regulations, and campaigns for awareness-raising were considered to pertain to public and state institutions. Bottom-up civic initiatives should be more concerned with activism, education, and awareness-raising.

\section{Conclusions}

The Delphi method aimed to assess policy options by extracting the most controversial elements. That is, although our aim was not to achieve consensus amongst stakeholders, we could identify an agreement on most of the most important questions.

- Implementing policies that encourage reduced use of inorganic $\mathrm{N}$ fertilizer is an important step towards a shift in the increased cultivation of legumes. It is not clear to what extent this would create an impact on the consumption of legumes.

- Investment in R\&D, agricultural extension services, and knowledge transfer is necessary to support the point above and allow for a smooth transition from high use of synthetic $\mathrm{N}$ fertilizer in conventional agriculture to precision farming and agroecological farming.

- Mitigation and adaptation strategies to combat climate change can have an indirect positive effect on legume production and consumption if these policies are implemented on a large scale and effectively. 
- Policies that tackle nutrition, health, and diet are relevant for the increase in legume consumption and, indirectly, legume production. However, preferences, culinary traditions, and cultural habits are difficult to change with top-down approaches or via promotional and information campaigns.

- Citizen-led initiatives that inform and educate the public on the environmental and health benefits of legume consumption should accompany policies that tackle production and farming strategies (i.e., greening payments with other agroecological and rural development incentives, etc.).

- The CAP is an important tool to support food production and protection of the natural environment, and of which the farm is a key component for the creation of any positive externalities. Hence, the CAP needs to be reoriented.

- Trade agreements are part of a complex web of interconnections between economies around the world, and any intervention will have repercussions along the food chain in general; therefore, this possibility is not advocated for.

A small number $(<5 \%)$ of participants highlighted the importance of framing incentives instead of "punishments" (taxes, penalties, etc.) more positively for the implementation of farming practices that include legumes in the farming plan (rotations, crop mixtures, intercropping). The EC "Green Deal" aims to stimulate such a policy framework, promoting positive incentives that may work in support of legume production and consumption. By 2050, European agriculture aims to be "carbon neutral," with goals set in the Climate Act, and Directives of Renewable Energy, Energy Efficiency, Land-use Change and Emission Trading. At least $40 \%$ of the overall CAP budget for 2021-2027 would contribute to "climate action." A reduction in carbon emissions may also be coupled with reduced use of synthetic fertilizers, especially $\mathrm{N}$, which need to be substituted by more environmentally friendly and diversification-focused practices, including increased legumes in the rotation, and more mixed (arable plus livestock) farmed units, which are largely self-sufficient in animal feed provision.

The most important sections of the Green Deal for the increased production and consumption of legumes are within the "Farm to Fork Strategy." The strategy aims at a "fair, healthy and environmentally-friendly food system" via the introduction of a new business model focusing on performance rather than compliance. Within this framework, ecoschemes reward farmers for improved environment and climate performance, including carbon capture and retention and improving nutrient management to enhance the quality of water and reduce GHG emissions. These practices shall be financially stimulated within the CAP and other public or private initiatives. The Loss of Nutrient Strategy entails a reduction in nutrient losses by $50 \%$ and a reduction in fertilizer use by $20 \%$ by 2030 . Reducing pesticide use ( $50 \%$ by 2050 ) is another strategy within the Green Deal that may favor R\&D investment in leguminous crops.

The Farm to Fork Strategy also aims to reduce food processing's environmental impact, launching a process to identify new innovative food and feed processes and products such as plant-protein-rich food. Lastly, the strategy will strive to stimulate sustainable food consumption and to give consumers better information on the provenience, nutritional value, and environmental footprint of food.

Hence, the Green Deal in general, and the Farm to Fork Strategy in particular, represent a substantial policy innovation that may positively impact legume production and consumption in the EU. The question remains: Will the strategy be well implemented in the various member states, and how will the barriers and system lock-ins be overcome? For example, in this study, the provision of R\&D and agricultural extension services was been as one of the most important policy instruments to increase legume production (and consumption) in Europe. However, this factor is not directly addressed in the Green Deal, and it may be a necessary factor for implementing such policy innovation. Oliver et al. (2018) [48] highlighted knowledge constraints as one of the mechanisms locking the food system into its current unsustainable state. Knowledge constraints include lack of access to specific skills and uncertainty regarding the benefits of alternative approaches-both 
of which are crucial aspects for the adoption of the Farm to Forks Strategy's ambitious goals by European farmers. Regional social "knowledge" or "learning clusters" and multistakeholder collaboration are considered necessary triggers of synergies in the bioeconomy to reduce financial barriers for innovators and SMEs (small and medium enterprises). Hassink (2005) [49] proposed learning clusters as focal points within which dependencies or lock-ins may be overcome. To implement effective regionalized social networking and education strategies, there is a need first to understand and manage the different processes of learning among the various value-chain clusters. Then, innovation-related regional actors (politicians, policymakers, chambers of commerce, trade unions, higher education institutes, public research establishments, and companies) can cooperatively and carefully identify resources in the region that could help foster development (anti-lock-ins). We support this view of empowering localized citizen-led regional clusters to implement policy innovations such as the Farm to Fork Strategy. This study identified policy interventions that can determine the future of legumes within the EU food system, and they concur with innovation policies proposed at the EU level, such as the Farm to Fork Strategy within the EU Green Deal. Nevertheless, future efforts should focus on discerning the details regarding the effective implementation of overarching policies. Systems lock-ins and path dependencies stem from well-established routines and capacities that are engrained and embedded in (often successful) local economies. Breaking lock-ins is key to the implementation of innovative policy instruments for the required rapid change toward more sustainable climate-positive cropped systems and healthier diets.

Author Contributions: Conceptualization, B.B., E.K., T.C., M.W.V., and P.P.M.I.; methodology, B.B., E.K., and T.C.; formal analysis, B.B., E.K., and T.C.; writing-original draft preparation, B.B., E.K., and T.C.; writing-review and editing, M.W.V. and P.P.M.I.; funding acquisition, M.W.V. and P.P.M.I. All authors have read and agreed to the published version of the manuscript.

Funding: TRUE (www.true-project).

Informed Consent Statement: Not applicable.

Data Availability Statement: The data presented in this study are openly available in Zenodo at http:/ / doi.org/10.5281/zenodo.4817334.

Acknowledgments: For successfully deploying the eDelphi (https:/ / www.edelphi.org/), the support from Hannu Linturi and Antti Kauppi at metodix.fi is greatly appreciated.

Conflicts of Interest: The authors declare no conflict of interest.

\section{Appendix A. Diagram of Codes Used for Text Analysis}

Explanation of Appendix A

Forty in vivo codes in the first round and 51 in vivo codes in the second round were grouped in six categories: (1) economics, (2) social, (3) environmental, (4) policies, (5) technology, and (6) farming. The mental model above shows logical links between the different categories.

In the economics category, we had one sub-category ("economic/business"), which included two codes (trade and marketing). Other codes included in the economics category were incentives, competition, value chain, demand, investment, and costs.

In the Social category there were nine codes: cultural barriers, tradition, values, preferences, complexity, health, consumption, education, and activism.

In the environmental category the six codes were sustainability, carbon sequestration, biodiversity, externalities, integrated/diversified farming, and greening measures; it also included one sub-category ("environmental/externalities") which consisted of the following codes: climate change, pollution, fertilizer, and pesticides.

In the policies category there were six codes and one sub-category with three codes. The six codes were subsidies, policy reforms, bans, regulatory policies, inertia, and sup- 
Sustainability 2021, 13, 7597

19 of 43

portive. The three codes for the sub-category "policies/bottlenecks" were systems lock-ins, risks, and bottlenecks.

In the technology/innovation category the five codes were processing, agricultural extension services, research, breeding, innovation, and knowledge.

In the farming category, there were eight codes: production, crops/arable area, meat/dairy, smallholder/small scale, nutrition, good agricultural practices, rotations, and pest resistance.

These codes were used to analyze the text of the comments and to quantify the codes that occurred most often (see Figure 4) in the comments for each scenario in Round 2.

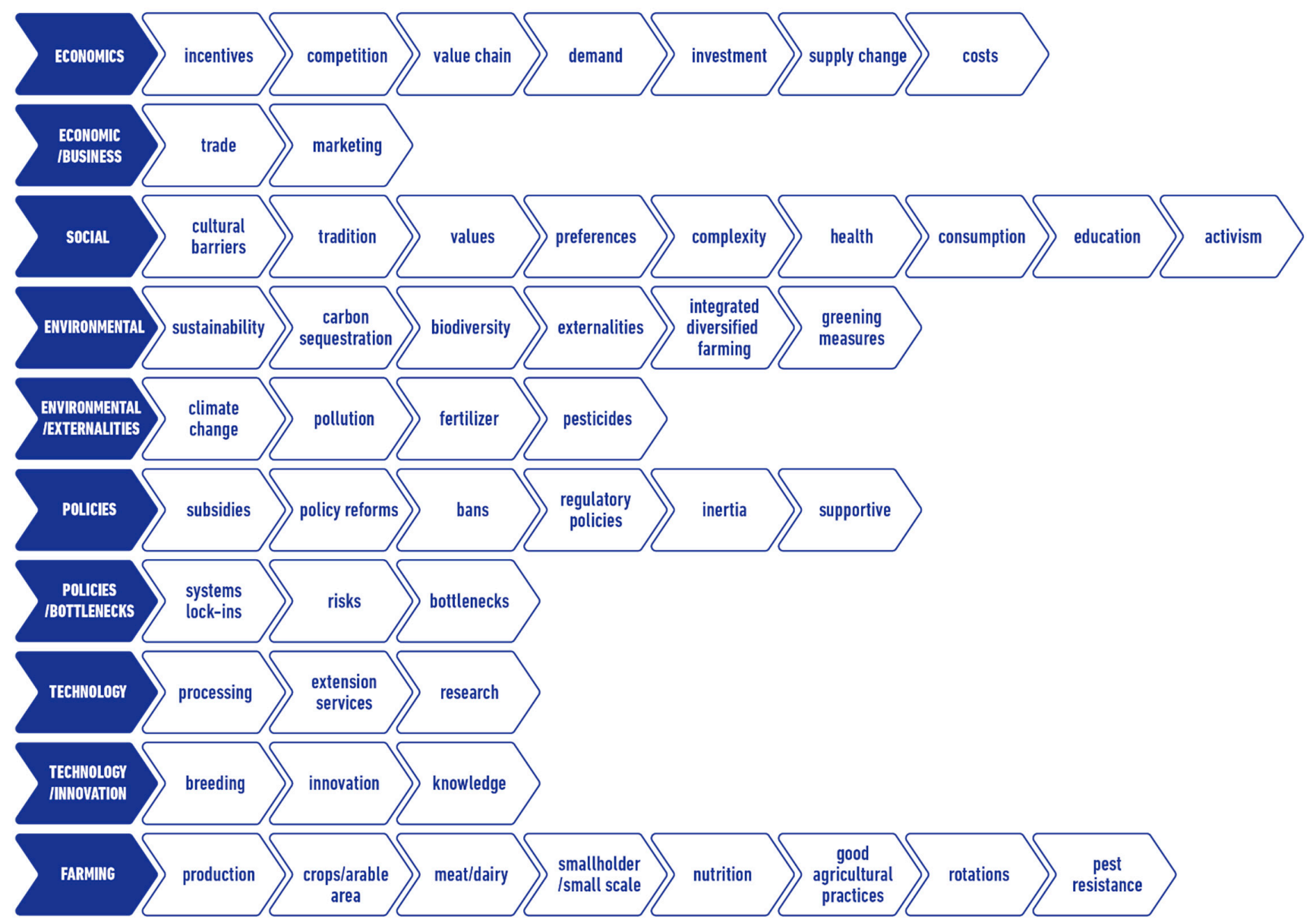


Appendix B. Extract of Codes for Each Category

Category: Economic

\begin{tabular}{|c|c|c|c|c|}
\hline Code & Case & Text & Number of Words & $\%$ Words \\
\hline Competition & Eliminate CAP & $\begin{array}{l}\text { Such a radical shift would drive } \\
\text { many European farmers out of } \\
\text { business and would have an impact } \\
\text { on food supply within Europe }\end{array}$ & 22 & $2.30 \%$ \\
\hline Competition & Eliminate CAP & $\begin{array}{l}\text { The fact that European land } \\
\text { resources are substantially lower } \\
\text { than those of other continents and } \\
\text { the unfair commerce practises }\end{array}$ & 19 & $2.00 \%$ \\
\hline Costs & Eliminate CAP & $\begin{array}{l}\text { Farmers may look for lower even } \\
\text { more their production costs (lower } \\
\text { their } \mathrm{N} \text { input usually in excess in } \\
\text { wet areas) better cropping practices } \\
\text { and many will not be part time } \\
\text { farmers. }\end{array}$ & 31 & $3.20 \%$ \\
\hline
\end{tabular}

\begin{tabular}{|c|c|c|c|c|}
\hline Competition & Eliminate CAP & $\begin{array}{l}\text { Farmers may look for lower even } \\
\text { more their production costs (lower } \\
\text { their N input usually in excess in } \\
\text { wet areas) better cropping practices } \\
\text { and many will not be part time } \\
\text { farmers. }\end{array}$ & 31 & $3.20 \%$ \\
\hline Marketing & Eliminate CAP & $\begin{array}{l}\text { Then production would be driven } \\
\text { only by the market, which is not } \\
\text { good for sustainability }\end{array}$ & 15 & $1.60 \%$ \\
\hline Incentives & Eliminate CAP & $\begin{array}{l}\text { Parts of the current CAP have } \\
\text { positive impacts (e.g., AE funding }\end{array}$ & 12 & $1.30 \%$ \\
\hline Competition & Eliminate CAP & The market will drive production & 8 & $0.80 \%$ \\
\hline Value chain & Eliminate CAP & $\begin{array}{l}\text { Would mean that the cheapest value } \\
\text { chains will drive most of the } \\
\text { production and consequently } \\
\text { consumption }\end{array}$ & 16 & $1.70 \%$ \\
\hline Costs & Eliminate CAP & Cost production must be reduced & 5 & $0.50 \%$ \\
\hline Incentives & Eliminate CAP & $\begin{array}{l}\text { Point is retail focus is still profit } \\
\text { driven. and cash to shareholders. if } \\
\text { there is no money to the farm, why } \\
\text { would you farm at all. }\end{array}$ & 26 & $2.70 \%$ \\
\hline Competition & Eliminate CAP & $\begin{array}{l}\text { Point is retail focus is still profit } \\
\text { driven. and cash to shareholders. if } \\
\text { there is no money to the farm, why } \\
\text { would you farm at all. }\end{array}$ & 26 & $2.70 \%$ \\
\hline Costs & Eliminate CAP & $\begin{array}{l}\text { Stopping subsidies without making } \\
\text { prices saying the truth as well for } \\
\text { local as for externally produced feed } \\
\text { and food will most likely reduce the } \\
\text { sustainability, i.e., the ability to } \\
\text { survive for most agriculture as it is } \\
\text { cheaper to produce outside Europe }\end{array}$ & 42 & $4.40 \%$ \\
\hline
\end{tabular}




\begin{tabular}{|c|c|c|c|c|}
\hline Code & Case & Text & Number of Words & $\%$ Words \\
\hline Competition & Eliminate CAP & $\begin{array}{l}\text { Stopping subsidies without making } \\
\text { prices saying the truth as well for } \\
\text { local as for externally produced feed } \\
\text { and food will most likely reduce the } \\
\text { sustainability, i.e., the ability to } \\
\text { survive for most agriculture as it is } \\
\text { cheaper to produce outside Europe }\end{array}$ & 42 & $4.40 \%$ \\
\hline Costs & Eliminate CAP & $\begin{array}{l}\text { Elimination of subsidy would have a } \\
\text { massive effect on all of agriculture } \\
\text { and would force those that remain } \\
\text { in production to adopt least cost } \\
\text { production methods }\end{array}$ & 26 & $2.70 \%$ \\
\hline Trade & Climate measures & $\begin{array}{l}\text { Will countries import meat and } \\
\text { dairy from outside? }\end{array}$ & 8 & $0.80 \%$ \\
\hline
\end{tabular}

I can also imagine that in a more competitive market for cereals and

vegetables it may become

Competition Climate measures advantageous to apply cheap mineral fertilizer (produced with

$4.00 \%$ cheap excess wind power) rather than introducing unreliable legumes in the crop rotation

This would demand a rapid Investment Climate measures investment in processing capacities for meat and dairy replacements generally stronger dis/incentives Incentives Climate measures are needed regarding home-grown legumes and their competition with cheap protein imports

Politically this is not feasible. The

changes in lifestyle and food

Costs Climate measures production would increase food costs significantly and be unsustainable.

\begin{tabular}{|c|c|c|c|c|}
\hline Competition & $\begin{array}{c}\text { Agricultural } \\
\text { extension services }\end{array}$ & $\begin{array}{l}\text { Question remains whether they are } \\
\text { financially competitive. }\end{array}$ & 7 & $0.80 \%$ \\
\hline Competition & $\begin{array}{c}\text { Agricultural } \\
\text { extension services }\end{array}$ & $\begin{array}{l}\text { Question remains whether they are } \\
\text { financially competitive }\end{array}$ & 7 & $0.80 \%$ \\
\hline Costs & $\begin{array}{c}\text { Agricultural } \\
\text { extension services }\end{array}$ & $\begin{array}{c}\text { Cost of their raw materials is } \\
\text { increased }\end{array}$ & 7 & $0.80 \%$ \\
\hline Incentives & $\begin{array}{c}\text { Agricultural } \\
\text { extension services }\end{array}$ & $\begin{array}{c}\text { This is a crucial point. Recovering } \\
\text { these services will have an impact if } \\
\text { demand, prices, consumption run } \\
\text { parallel }\end{array}$ & 18 & $2.10 \%$ \\
\hline Value chain & $\begin{array}{c}\text { Agricultural } \\
\text { extension services }\end{array}$ & $\begin{array}{l}\text { Sharing of the added value all along } \\
\text { the value chain }\end{array}$ & 10 & $1.10 \%$ \\
\hline Demand & $\begin{array}{c}\text { Agricultural } \\
\text { extension services }\end{array}$ & $\begin{array}{l}\text { Advisors will generally increase } \\
\text { their interest with the increased } \\
\text { exposure to the crop and demand } \\
\text { for advice. }\end{array}$ & 17 & $1.90 \%$ \\
\hline
\end{tabular}




\begin{tabular}{|c|c|c|c|c|}
\hline Code & Case & Text & Number of Words & $\%$ Words \\
\hline Incentives & $\begin{array}{c}\text { Agricultural } \\
\text { extension services }\end{array}$ & $\begin{array}{l}\text { Their education will not necessarily } \\
\text { in itself drive increased production. } \\
\text { Growers preferably need to be able } \\
\text { to make money from any crop or be } \\
\text { made/encouraged to grow them for } \\
\text { environmental/sustainability } \\
\text { objective reasons }\end{array}$ & 34 & $3.90 \%$ \\
\hline Trade & $\begin{array}{l}\text { Regulating synthetic } \\
\text { N use }\end{array}$ & $\begin{array}{l}\text { Maybe in increase of cheaper } \\
\text { imports }\end{array}$ & 6 & $0.40 \%$ \\
\hline Demand & $\begin{array}{l}\text { Regulating synthetic } \\
\text { N use }\end{array}$ & $\begin{array}{l}\text { Legume production is primarily } \\
\text { linked to demand and prices. }\end{array}$ & 9 & $0.50 \%$ \\
\hline Costs & $\begin{array}{l}\text { Nutrition, diet, and } \\
\text { health }\end{array}$ & $\begin{array}{l}\text { I would expect education to have a } \\
\text { marginal impact on demand }\end{array}$ & 14 & $1.50 \%$ \\
\hline Marketing & $\begin{array}{l}\text { Nutrition, diet, and } \\
\text { health }\end{array}$ & $\begin{array}{l}\text { New market for quality pulses } \\
\text { which will increase demand }\end{array}$ & 9 & $0.90 \%$ \\
\hline
\end{tabular}

At present this is likely to be supplied by North American producers rather than EU farmers as

Nutrition, diet, and the R\&D is not being undertaken by
Investment $\quad$ EU based organisations. Major health

investment in this area being made in Canada and US by food companies supported by public funds.

\begin{tabular}{|c|c|c|c|c|}
\hline Incentives & $\mathrm{R} \& \mathrm{D}$ & $\begin{array}{l}\text { What sort of incentives will be } \\
\text { allowed to farmers (such as } \\
\text { participation schemes?) }\end{array}$ & 16 & $1.40 \%$ \\
\hline Demand & $\mathrm{R} \& \mathrm{D}$ & Mainly its profitability for farmers & 5 & $0.40 \%$ \\
\hline Investment & $\mathrm{R} \& \mathrm{D}$ & $\begin{array}{c}\text { Investment in legume crop } \\
\text { development at the farm level is } \\
\text { needed urgently. }\end{array}$ & 12 & $1.10 \%$ \\
\hline Investment & $\mathrm{R} \& \mathrm{D}$ & $\begin{array}{l}\text { Investment in new and novel } \\
\text { processing will create market } \\
\text { demand and the opportunity for } \\
\text { growers to profit by supplying new } \\
\text { markets with added value. I see } \\
\text { investment in new varieties of } \\
\text { legumes as important }\end{array}$ & 34 & $3.00 \%$ \\
\hline Demand & Trade policy & $\begin{array}{l}\text { It would improve their place in the } \\
\text { market }\end{array}$ & 7 & $0.50 \%$ \\
\hline Costs & Trade policy & $\begin{array}{l}\text { Perhaps they would be happy to pay } \\
\text { this cost }\end{array}$ & 9 & $0.70 \%$ \\
\hline Competition & Trade policy & $\begin{array}{l}\text { Increased environmental, safety and } \\
\text { ethical standards for imported raw } \\
\text { protein sources will inevitably raise } \\
\text { the competitiveness of homegrown } \\
\text { legumes. }\end{array}$ & 19 & $1.40 \%$ \\
\hline Competition & Trade policy & Competitiveness of EU legumes & 4 & $0.30 \%$ \\
\hline Trade & Trade policy & $\begin{array}{l}\text { Legume exporter for food towards } \\
\text { countries able to pay for. }\end{array}$ & 10 & $0.70 \%$ \\
\hline
\end{tabular}




\begin{tabular}{|c|c|c|c|c|}
\hline Code & Case & Text & Number of Words & $\%$ Words \\
\hline Competition & Trade policy & $\begin{array}{l}\text { It will potentially increase } \\
\text { competitiveness of prices of EU } \\
\text { legumes. fact is many classes for } \\
\text { food consumption are not } \\
\text { sufficiently grown in Europe today. }\end{array}$ & 24 & $1.80 \%$ \\
\hline Trade & Trade policy & $\begin{array}{l}\text { This means trade barriers and } \\
\text { restrictions on imports of products } \\
\text { that do not meet the standards. This } \\
\text { will only impact the EU production } \\
\text { if the barriers can be made to stick } \\
\text { and the cost of meeting the } \\
\text { standards is so high that they cannot } \\
\text { be overcome without cost } \\
\text { implications that make the imports } \\
\text { economically uncompetitive. For } \\
\text { this lack of clarity, I have not ranked } \\
\text { the }+/- \text { effect. }\end{array}$ & 66 & $4.90 \%$ \\
\hline
\end{tabular}

Category: Social

\begin{tabular}{|c|c|c|c|c|}
\hline Code & Case & Text & Number of Words & $\%$ Words \\
\hline Complexity & Eliminate CAP & $\begin{array}{l}\text { There are too many influences } \\
\text { linked with that. Hard to say } \\
\text { anything about impact }\end{array}$ & 14 & $1.50 \%$ \\
\hline Complexity & Eliminate CAP & $\begin{array}{l}\text { A huge agri-food turmoil is to be } \\
\text { expected }\end{array}$ & 8 & $0.80 \%$ \\
\hline Complexity & Eliminate CAP & $\begin{array}{l}\text { If ALL subsidies would be cut, we } \\
\text { would get a revolution. There would } \\
\text { be no essential impact on legume } \\
\text { production }\end{array}$ & 20 & $2.10 \%$ \\
\hline Consumption & $\begin{array}{l}\text { Agricultural } \\
\text { extension services }\end{array}$ & $\begin{array}{l}\text { For consumption there should be no } \\
\text { impact. For a sustainable agriculture } \\
\text { a better knowledge and entrance to } \\
\text { resources would have a bigger } \\
\text { impact. }\end{array}$ & 23 & $2.60 \%$ \\
\hline Consumption & $\begin{array}{l}\text { Regulating synthetic } \\
\text { N use }\end{array}$ & $\begin{array}{l}\text { Synthetic } \mathrm{N} \text { might give a mild push } \\
\text { to legume production but none to } \\
\text { consumption, as several other } \\
\text { commentators have noted }\end{array}$ & 20 & $1.20 \%$ \\
\hline Consumption & $\begin{array}{l}\text { Regulating synthetic } \\
\text { N use }\end{array}$ & $\begin{array}{l}\text { Then, since they would be more } \\
\text { readily available in the EU market, } \\
\text { their consumption would increase at } \\
\text { a second step }\end{array}$ & 20 & $1.20 \%$ \\
\hline Preferences & $\begin{array}{l}\text { Regulating synthetic } \\
\text { N use }\end{array}$ & $\begin{array}{l}\text { Increasing legume consumption as } \\
\text { foods is a harder business as it } \\
\text { requires a substantial increase in } \\
\text { many European countries and a } \\
\text { change in dietary habits which } \\
\text { usually takes a rather long time to } \\
\text { occur }\end{array}$ & 34 & $2.10 \%$ \\
\hline Preferences & $\begin{array}{l}\text { Regulating synthetic } \\
\text { N use }\end{array}$ & $\begin{array}{l}\text { To increase consumption is also } \\
\text { necessary to make awareness raising } \\
\text { campaigns }\end{array}$ & 11 & $0.70 \%$ \\
\hline
\end{tabular}




\begin{tabular}{|c|c|c|c|c|}
\hline Code & Case & Text & Number of Words & $\%$ Words \\
\hline Consumption & $\begin{array}{l}\text { Regulating synthetic } \\
\text { N use }\end{array}$ & $\begin{array}{l}\text { Will people consume more pulses } \\
\text { directly as food?-probably yes BUT } \\
\text { not due to the measures posed in } \\
\text { this question }\end{array}$ & 20 & $1.20 \%$ \\
\hline Consumption & $\begin{array}{l}\text { Regulating synthetic } \\
\text { N use }\end{array}$ & $\begin{array}{l}\text { Consumers ask already today for } \\
\text { healthy legumes; a more vegetarian } \\
\text { diet will increase and with that the } \\
\text { consumption of legumes }\end{array}$ & 20 & $1.20 \%$ \\
\hline Consumption & $\begin{array}{l}\text { Regulating synthetic } \\
\text { N use }\end{array}$ & $\begin{array}{l}\text { Improvement/increases in } \\
\text { consumption is likely, in that } \\
\text { production can be a driver for } \\
\text { consumption in the case of legumes, } \\
\text { i.e., increased production has the } \\
\text { potential to increase consumption }\end{array}$ & 30 & $1.80 \%$ \\
\hline Preferences & $\begin{array}{l}\text { Nutrition, diet, and } \\
\text { health }\end{array}$ & $\begin{array}{l}\text { If calories-intake is to be reduced } \\
\text { this could mean less meat not } \\
\text { necessarily more legumes. Humans } \\
\text { like and eat food not only because of } \\
\text { its nutritional value but because } \\
\text { they enjoy the taste, flavour, and } \\
\text { texture etc. I think people are more } \\
\text { willing to change their diet slightly } \\
\text { for a greater environmental benefit } \\
\text { than for personal health. }\end{array}$ & 58 & $6.10 \%$ \\
\hline Preferences & $\begin{array}{l}\text { Nutrition, diet, and } \\
\text { health }\end{array}$ & $\begin{array}{l}\text { The question is how to get it into } \\
\text { consumer hands and then how to } \\
\text { get them to use it. Mild positives in } \\
\text { both axes as the outcome would be } \\
\text { reduced consumption of animal } \\
\text { products, with all of its on-costs, and } \\
\text { mild increases in plant-protein } \\
\text { production. }\end{array}$ & 47 & $4.90 \%$ \\
\hline Complexity & $\begin{array}{l}\text { Nutrition, diet, and } \\
\text { health }\end{array}$ & $\begin{array}{l}\text { I think the measures suggested are } \\
\text { important to increase the awareness } \\
\text { of the health and environmental } \\
\text { benefits related to increased legume } \\
\text { food consumption for individuals. } \\
\text { However, it is not enough to lead to } \\
\text { significant changes in consumption } \\
\text { patterns }\end{array}$ & 38 & $4.00 \%$ \\
\hline Cultural Barriers & $\begin{array}{l}\text { Nutrition, diet, and } \\
\text { health }\end{array}$ & $\begin{array}{l}\text { We need to have a bigger variety of } \\
\text { legume foods at market and they } \\
\text { need to fit into the local food culture } \\
\text { and have favourable sensory } \\
\text { properties. }\end{array}$ & 27 & $2.80 \%$ \\
\hline Tradition & $\begin{array}{l}\text { Nutrition, diet, and } \\
\text { health }\end{array}$ & $\begin{array}{l}\text { It would be important to route } \\
\text { legumes and legume-supported } \\
\text { foods into cultures in forms that } \\
\text { were very tasty and in-line with } \\
\text { their cultural expectations. }\end{array}$ & 30 & $3.10 \%$ \\
\hline
\end{tabular}




\begin{tabular}{|c|c|c|c|c|}
\hline Code & Case & Text & Number of Words & $\%$ Words \\
\hline Tradition & $\begin{array}{l}\text { Nutrition, diet, and } \\
\text { health }\end{array}$ & $\begin{array}{l}\text { Under confinement in Spain the } \\
\text { increase in the use of grain legumes } \\
\text { in the diets has increased } \\
\text { significantly: the reason that was } \\
\text { given was mainly parents or families } \\
\text { had more time for cooking. so the } \\
\text { demand is there built in the } \\
\text { traditions and also nowadays the } \\
\text { gourmet approaches }\end{array}$ & 48 & $5.00 \%$ \\
\hline Heatlh & $\begin{array}{l}\text { Nutrition, diet, and } \\
\text { health }\end{array}$ & $\begin{array}{l}\text { Proteins especially legumes in } \\
\text { human diets will increase } \\
\text { significantly over the next } 10 \text { years. } \\
\text { They will not only be a source of } \\
\text { protein but provide healthier forms } \\
\text { of carbohydrate, fibre, mineral and } \\
\text { vitamins }\end{array}$ & 33 & $3.50 \%$ \\
\hline Heatlh & $\begin{array}{l}\text { Nutrition, diet, and } \\
\text { health }\end{array}$ & $\begin{array}{l}\text { Dietary guidelines on reduction of } \\
\text { meat consumption and increase of } \\
\text { pulses have already shown to have } \\
\text { impact on consumption and } \\
\text { therewith on public health. }\end{array}$ & 24 & $2.50 \%$ \\
\hline Consumption & $\begin{array}{l}\text { Nutrition, diet, and } \\
\text { health }\end{array}$ & $\begin{array}{l}\text { Dietary guidelines on reduction of } \\
\text { meat consumption and increase of } \\
\text { pulses have already shown to have } \\
\text { impact on consumption and } \\
\text { therewith on public health. }\end{array}$ & 24 & $2.50 \%$ \\
\hline Consumption & $\begin{array}{l}\text { Nutrition, diet, and } \\
\text { health }\end{array}$ & $\begin{array}{l}\text { Consumer education and awareness } \\
\text { campaigns have already led to } \\
\text { increased consumption }\end{array}$ & 11 & $1.20 \%$ \\
\hline
\end{tabular}

Category: Environmental

\begin{tabular}{ccccc}
\hline Code & Case & Text & Words & \% Words \\
\hline Sustainability & Eliminate CAP & $\begin{array}{c}\text { So environmental standards would } \\
\text { still be in effect, but farmers are not } \\
\text { compensated? I think this would } \\
\text { lead to economically efficient } \\
\text { large-scale agriculture with little } \\
\text { regard to biodiversity. }\end{array}$ & 29 & $3.00 \%$ \\
\hline Sustainability & Eliminate CAP & $\begin{array}{c}\text { Positive effects on sustainability. So } \\
\text { far, it has had a little positive effect } \\
\text { on legume production after the 2013 } \\
\text { reforms that followed decades of } \\
\text { negative effects whether intended or } \\
\text { not }\end{array}$ & 30 & $3.10 \%$ \\
\hline Sustainability & Eliminate CAP & $\begin{array}{c}\text { It would make the abandonment of } \\
\text { subsidies to threat of EU agriculture } \\
\text { sustainability. }\end{array}$ & 12 & $1.30 \%$ \\
\hline Externalities & Eliminate CAP & $\begin{array}{c}\text { I think global food prices are not } \\
\text { determined by the true costs of } \\
\text { production but nearly every nation } \\
\text { subsides food production somewhat }\end{array}$ & 22 & $2.30 \%$ \\
\hline Sustainability & Eliminate CAP & Which is not good for sustainability & 6 & $0.60 \%$ \\
\hline
\end{tabular}




\begin{tabular}{|c|c|c|c|c|}
\hline Code & Case & Text & Words & $\%$ Words \\
\hline Sustainability & Eliminate CAP & $\begin{array}{l}\text { Other parts are totally } \\
\text { counterproductive in many ways } \\
\text { (e.g., subsidies without a clear social } \\
\text { or environmental benefit }\end{array}$ & 18 & $1.90 \%$ \\
\hline Sustainability & Eliminate CAP & $\begin{array}{l}\text { A thought about eliminating } \\
\text { subsidies, but their careful } \\
\text { deployment can be vital for } \\
\text { ecological regeneration }\end{array}$ & 15 & $1.60 \%$ \\
\hline Sustainability & Eliminate CAP & Sustainability might be improved & 5 & $0.50 \%$ \\
\hline Climate change & Eliminate CAP & $\begin{array}{l}\text { Add the climate change with more } \\
\text { crop failures. you will probably rule } \\
\text { out farming }\end{array}$ & 14 & $1.50 \%$ \\
\hline Externalities & Eliminate CAP & $\begin{array}{l}\text { The question is how to make prices } \\
\text { say the truth AND at the same time } \\
\text { make sure that production will be } \\
\text { massively reduced }\end{array}$ & 23 & $2.40 \%$ \\
\hline Climate change & Eliminate CAP & $\begin{array}{l}\text { However, climate change may work } \\
\text { in our favour as other regions will } \\
\text { suffer even more from climate } \\
\text { change than central Europe and then } \\
\text { it may be realistic to make the prices } \\
\text { say the truth }\end{array}$ & 34 & $3.60 \%$ \\
\hline
\end{tabular}

Which would involve the much greater use of legumes to provide $\mathrm{N}$ Fertilizer Eliminate CAP and improve soil fertility. The shock would be huge, right along the value chain.

Which would involve the much greater use of legumes to provide $\mathrm{N}$ Sustainability Eliminate CAP and improve soil fertility. The shock would be huge, right along the value chain.

What effects is this going to have on smallholders in other countries (increased pressure on land? more pollution of water and deterioration Sustainability Climate measures of soil?) The question should not be whether meat and dairy should be produced or not but rather in which forms? What kind of production systems can be rated sustainable

Mixed, diverse production systems

Integrated/diversified farming
Climate measures rate higher in this regard and they are also more resilient. But animals are an important part of such systems. 


\begin{tabular}{|c|c|c|c|c|}
\hline Code & Case & Text & Words & $\%$ Words \\
\hline Biodiversity & Climate measures & $\begin{array}{l}\text { I am very uncertain about my } \\
\text { answer, but my feeling is there is } \\
\text { going to be a negative effect on } \\
\text { legumes and overall sustainability } \\
\text { by such a radical move. } \\
\text { Sustainability will decrease because } \\
\text { biodiversity associated with } \\
\text { temporary and permanent } \\
\text { grasslands will drastically decrease. }\end{array}$ & 44 & $4.60 \%$ \\
\hline Fertilizer & Climate measures & $\begin{array}{l}\text { It may be advantageous to apply } \\
\text { cheap mineral fertilizer (produced } \\
\text { with cheap excess wind power) } \\
\text { rather than introducing unreliable } \\
\text { legumes in the crop rotation. If } \\
\text { legumes have become a reliable } \\
\text { source of income by then, more } \\
\text { legumes would be used (maybe also } \\
\text { due to a high demand for products } \\
\text { replacing meat and dairy }\end{array}$ & 51 & $5.30 \%$ \\
\hline Sustainability & Climate measures & $\begin{array}{l}\text { In such a case there would be a } \\
\text { positive effect on production but a } \\
\text { mild effect on sustainability }\end{array}$ & 18 & $1.90 \%$ \\
\hline Sustainability & Climate measures & $\begin{array}{l}\text { Banning meat and dairy } \\
\text { consumption altogether is not the } \\
\text { solution for our environmental } \\
\text { problems and might even have a } \\
\text { negative impact on sustainability }\end{array}$ & 23 & $2.40 \%$ \\
\hline Biodiversity & Climate measures & $\begin{array}{l}\text { On the other hand, we need grazing } \\
\text { animals to use pastures (we cannot } \\
\text { use cellulose) and crops that will not } \\
\text { produce in dry years. }\end{array}$ & 24 & $2.50 \%$ \\
\hline $\begin{array}{c}\text { Carbon } \\
\text { sequestration }\end{array}$ & Climate measures & $\begin{array}{l}\text { Animal production plays a role and } \\
\text { C sequestration too. }\end{array}$ & 14 & $1.50 \%$ \\
\hline Sustainability & Climate measures & $\begin{array}{l}\text { Again, scored on production as the } \\
\text { studies undertaken on choice } \\
\text { experiments have shown that what } \\
\text { consumers say they do and how } \\
\text { they behave are very different. } \\
\text { Again, similar concerns with } \\
\text { sustainability metrics as outlined in } \\
\text { previous answers. }\end{array}$ & 37 & $3.90 \%$ \\
\hline Sustainability & Climate measures & $\begin{array}{l}\text { Consumption would inevitably } \\
\text { increase because animal protein } \\
\text { sources are missing. Production } \\
\text { would increase accordingly. But the } \\
\text { sustainability would be negative, } \\
\text { because (a) it would not be political } \\
\text { realistic to reach such restrictions } \\
\text { and (b) there are too many regions } \\
\text { which depend on milk and meat } \\
\text { production-also to keep the } \\
\text { traditional cultural landscapes with } \\
\text { their biodiversity }\end{array}$ & 56 & $5.90 \%$ \\
\hline
\end{tabular}




\begin{tabular}{|c|c|c|c|c|}
\hline Code & Case & Text & Words & $\%$ Words \\
\hline Sustainability & Climate measures & $\begin{array}{l}\text { Some ecosystem services, including } \\
\text { those required for legume } \\
\text { production, can benefit from } \\
\text { non-intensive livestock industries. } \\
\text { Without legume-source livestock } \\
\text { feed, production would necessarily } \\
\text { decrease. }\end{array}$ & 25 & $2.60 \%$ \\
\hline Sustainability & $\begin{array}{c}\text { Agricultural } \\
\text { extension services }\end{array}$ & $\begin{array}{l}\text { Sustainability at landscape scale and } \\
\text { beyond. }\end{array}$ & 7 & $0.80 \%$ \\
\hline Sustainability & $\begin{array}{c}\text { Agricultural } \\
\text { extension services }\end{array}$ & $\begin{array}{l}\text { Aspects since sustainability } \\
\text { depends. }\end{array}$ & 4 & $0.50 \%$ \\
\hline Sustainability & $\begin{array}{l}\text { Agricultural } \\
\text { extension services }\end{array}$ & $\begin{array}{l}\text { Transforming EU agriculture; } \\
\text { therefore, they would result in } \\
\text { improving legume production and } \\
\text { agriculture sustainability. }\end{array}$ & 14 & $1.60 \%$ \\
\hline Fertilizer & $\begin{array}{c}\text { Agricultural } \\
\text { extension services }\end{array}$ & $\begin{array}{l}\text { Agrochemical (especially fertiliser) } \\
\text { suppliers. }\end{array}$ & 4 & $0.50 \%$ \\
\hline Sustainability & $\begin{array}{c}\text { Agricultural } \\
\text { extension services }\end{array}$ & $\begin{array}{l}\text { Higher impact on sustainability, } \\
\text { legumes production and } \\
\text { consumption are not directly } \\
\text { affected. }\end{array}$ & 12 & $1.40 \%$ \\
\hline Externalities & $\begin{array}{l}\text { Regulating synthetic } \\
\text { N use }\end{array}$ & $\begin{array}{l}\text { Restrictions on pesticide use would } \\
\text { also be needed. }\end{array}$ & 8 & $0.50 \%$ \\
\hline Biodiversity & $\begin{array}{l}\text { Regulating synthetic } \\
\text { N use }\end{array}$ & $\begin{array}{l}\text { Towards more integrated and } \\
\text { diverse systems and would support } \\
\text { biodiversity, water quality, soil } \\
\text { quality etc. at the same time. }\end{array}$ & 19 & $1.20 \%$ \\
\hline $\begin{array}{l}\text { Integrated/diversified } \\
\text { farming }\end{array}$ & $\begin{array}{l}\text { Regulating synthetic } \\
\text { N use }\end{array}$ & $\begin{array}{l}\text { Towards more integrated and } \\
\text { diverse systems and would support } \\
\text { biodiversity, water quality, soil } \\
\text { quality etc. at the same time. }\end{array}$ & 19 & $1.20 \%$ \\
\hline $\begin{array}{l}\text { Integrated/diversified } \\
\text { farming }\end{array}$ & $\begin{array}{l}\text { Regulating synthetic } \\
\text { N use }\end{array}$ & $\begin{array}{l}\text { Geographical redistribution of } \\
\text { livestock farming (or more likely } \\
\text { increase of slurry trafficking). }\end{array}$ & 13 & $0.80 \%$ \\
\hline Sustainability & $\begin{array}{l}\text { Regulating synthetic } \\
\qquad \mathrm{N} \text { use }\end{array}$ & $\begin{array}{l}\text { How is the sustainability being } \\
\text { assessed? If one were to incorporate } \\
\text { all of the costs and benefits } \\
\text { associated with the use of synthetic } \\
\mathrm{N} \text { vs legumes the answer may not be } \\
\text { straight forward as it will be highly } \\
\text { dependent upon associated land } \\
\text { management practises, type of } \\
\text { legumes and region. In other words, } \\
\text { it is very context dependent and } \\
\text { again reliant on the wider policy mix } \\
\text { and implementation. }\end{array}$ & 67 & $4.10 \%$ \\
\hline Sustainability & $\begin{array}{l}\text { Regulating synthetic } \\
\text { N use }\end{array}$ & $\begin{array}{l}\text { Sustainability improvement is } \\
\text { certain. }\end{array}$ & 4 & $0.20 \%$ \\
\hline Fertilizer & $\begin{array}{l}\text { Regulating synthetic } \\
\text { N use }\end{array}$ & $\begin{array}{l}\text { The legumes might replace or } \\
\text { reduce the application of fertilizers. }\end{array}$ & 10 & $0.60 \%$ \\
\hline
\end{tabular}




\begin{tabular}{|c|c|c|c|c|}
\hline Code & Case & Text & Words & \% Words \\
\hline $\begin{array}{l}\text { Integrated/diversified } \\
\text { farming }\end{array}$ & $\begin{array}{c}\text { Regulating synthetic } \\
\text { N use }\end{array}$ & $\begin{array}{l}\text { I think that this policy change is } \\
\text { going to have a positive impact on } \\
\text { organic farming in European } \\
\text { agriculture.... Increase of organic } \\
\text { farmers and certified bio products. }\end{array}$ & 27 & $1.60 \%$ \\
\hline $\begin{array}{l}\text { Integrated/diversified } \\
\text { farming }\end{array}$ & Trade policy & $\begin{array}{l}\text { The impact on sustainability is likely } \\
\text { to increase slightly but other } \\
\text { measures are needed at the same } \\
\text { time to switch to more integrated } \\
\text { and diverse systems. }\end{array}$ & 26 & $1.90 \%$ \\
\hline Sustainability & Trade policy & $\begin{array}{l}\text { As with sustainability my concerns } \\
\text { from the previous question would } \\
\text { be the same. If one were to view the } \\
\text { production of legumes across the } \\
\text { whole of Europe would the } \\
\text { sustainability from cradle to grave } \\
\text { actually be better than those } \\
\text { produced elsewhere. }\end{array}$ & 44 & $3.30 \%$ \\
\hline
\end{tabular}

Category: Policy

\begin{tabular}{|c|c|c|c|c|}
\hline Code & Case & Text & Words & $\%$ Words \\
\hline Subsidies & Eliminate CAP & $\begin{array}{l}\text { Environmental standards would still } \\
\text { be in effect, but farmers are not } \\
\text { compensated. }\end{array}$ & 12 & $1.30 \%$ \\
\hline Bans & Eliminate CAP & $\begin{array}{l}\text { I think that this is about as likely as } \\
\text { banning meat or pigs learning to fly. }\end{array}$ & 16 & $1.70 \%$ \\
\hline Policy reforms & Eliminate CAP & $\begin{array}{c}\text { This is not to say that we should not } \\
\text { think about making changes to } \\
\text { subsides. }\end{array}$ & 15 & $1.60 \%$ \\
\hline Policy reforms & Eliminate CAP & $\begin{array}{l}\text { This may need means tested } \\
\text { somehow. On a country/region } \\
\text { and/or farmer by farmer basis. }\end{array}$ & 16 & $1.70 \%$ \\
\hline Policy reforms & Eliminate CAP & $\begin{array}{l}\text { They do have to be entirely } \\
\text { refocused around sustainability } \\
\text { concerns. }\end{array}$ & 10 & $1.00 \%$ \\
\hline Policy reforms & Eliminate CAP & $\begin{array}{l}\text { Give us such ideas about the general } \\
\text { possibilities for the agri-food sector } \\
\text { (and also about the EU structural } \\
\text { organization for what matters. }\end{array}$ & 23 & $2.40 \%$ \\
\hline Policy reforms & Eliminate CAP & $\begin{array}{l}\text { The massive cost of Covd19 will } \\
\text { have a major impact on EU } \\
\text { economies over the next } 10 \text { years. } \\
\text { Political pressure will be to reduce } \\
\text { public expenditure and farm } \\
\text { subsidies will be questioned. There } \\
\text { will not be the funds available to } \\
\text { support agriculture as in the past. } \\
\text { The impact on EU legume } \\
\text { production and farm sustainability } \\
\text { may not be great but the impact on } \\
\text { farming will be enormous. }\end{array}$ & 67 & $7.00 \%$ \\
\hline
\end{tabular}




\begin{tabular}{|c|c|c|c|c|}
\hline Code & Case & Text & Words & $\%$ Words \\
\hline Subsidies & Eliminate CAP & $\begin{array}{l}\text { It would be of danger for the small } \\
\text { farmers, because the big ones have } \\
\text { enough resources for the beginning } \\
\text { and enough political influence to get } \\
\text { any public money. }\end{array}$ & 28 & $2.90 \%$ \\
\hline Inertia & Climate measures & $\begin{array}{l}\text { If this happens, then the impact will } \\
\text { be positive. The problem is: how } \\
\text { likely is that anything so radical will } \\
\text { happen? It seems to me times are } \\
\text { not ripe yet (which sounds crazy } \\
\text { and forces us to question: then what } \\
\text { will have the necessary effect?). }\end{array}$ & 45 & $4.70 \%$ \\
\hline Regulatory policies & Climate measures & $\begin{array}{l}\text { Regulatory measurements have the } \\
\text { highest impact on both. }\end{array}$ & 8 & $0.80 \%$ \\
\hline Regulatory policies & $\begin{array}{c}\text { Agricultural } \\
\text { extension services }\end{array}$ & $\begin{array}{l}\text { Are crucial for turning regulatory } \\
\text { conditions into profitability. }\end{array}$ & 8 & $0.90 \%$ \\
\hline Policy reforms & $\begin{array}{c}\text { Agricultural } \\
\text { extension services }\end{array}$ & $\begin{array}{l}\text { The new CAP is considering backing } \\
\text { agricultural extension services. }\end{array}$ & 8 & $0.90 \%$ \\
\hline System lock-ins & $\begin{array}{l}\text { Agricultural } \\
\text { extension services }\end{array}$ & $\begin{array}{l}\text { To advise on growing legumes. } \\
\text { Many consultants don't know much } \\
\text { about legumes. So, it has to start } \\
\text { from the scratch. }\end{array}$ & 21 & $2.40 \%$ \\
\hline Policy reforms & $\begin{array}{l}\text { Agricultural } \\
\text { extension services }\end{array}$ & $\begin{array}{l}\text { Major obstacle. So if serious efforts } \\
\text { to reboot this service were done. }\end{array}$ & 12 & $1.40 \%$ \\
\hline Policy reforms & $\begin{array}{l}\text { Agricultural } \\
\text { extension services }\end{array}$ & $\begin{array}{l}\text { To rethink them-so, in my reply I } \\
\text { imagined that if this policy will also } \\
\text { touch upon this, then I definitely see } \\
\text { a positive outcome. }\end{array}$ & 25 & $2.80 \%$ \\
\hline System lock-ins & $\begin{array}{c}\text { Agricultural } \\
\text { extension services }\end{array}$ & $\begin{array}{l}\text { Training and thus also not part of } \\
\text { the advisory work in most places } \\
\text { one of the main stumbling blocks. }\end{array}$ & 19 & $2.20 \%$ \\
\hline Policy reforms & $\begin{array}{l}\text { Agricultural } \\
\text { extension services }\end{array}$ & $\begin{array}{l}\text { Which is why policy tools that direct } \\
\text { the operation of the 'market' is } \\
\text { important. }\end{array}$ & 14 & $1.60 \%$ \\
\hline Regulatory policies & $\begin{array}{l}\text { Regulating synthetic } \\
\qquad \mathrm{N} \text { use }\end{array}$ & $\begin{array}{c}\text { Future regulations will play a role in } \\
\text { inclusion of legume in crop } \\
\text { rotations. }\end{array}$ & 13 & $0.80 \%$ \\
\hline Policy reforms & $\begin{array}{l}\text { Regulating synthetic } \\
\text { N use }\end{array}$ & $\begin{array}{l}\text { Policies aimed at restricting } \\
\text { synthetic } \mathrm{N} \text { use will surely enhance } \\
\text { legume area and production. }\end{array}$ & 14 & $0.90 \%$ \\
\hline Regulatory policies & $\begin{array}{l}\text { Regulating synthetic } \\
\text { N use }\end{array}$ & $\begin{array}{l}\text { Stricter environmental and climate } \\
\text { regulations related to synthetic } \mathrm{N} \\
\text { use will inevitably lead to } \\
\text { favourable changes in cropping } \\
\text { patterns and practices. }\end{array}$ & 21 & $1.30 \%$ \\
\hline
\end{tabular}




\begin{tabular}{|c|c|c|c|c|}
\hline Code & Case & Text & Words & $\%$ Words \\
\hline Policy reforms & $\begin{array}{l}\text { Regulating synthetic } \\
\text { N use }\end{array}$ & $\begin{array}{l}\text { Awareness/acceptance of the role that } \\
\text { legumes play in the system of fixing N. } \\
\text { As a standalone lever this is unlikely } \\
\text { to affect significant change if there are } \\
\text { not concurrent levers affecting } \\
\text { awareness raising, R\&D and } \\
\text { implementation guidance, etc. }\end{array}$ & 40 & $2.40 \%$ \\
\hline System lock-ins & $\begin{array}{l}\text { Regulating synthetic } \\
\text { N use }\end{array}$ & $\begin{array}{l}\text { The temptation is to believe that } \\
\text { farmers would embrace grain } \\
\text { legumes wholeheartedly, but they } \\
\text { need also to be able to make a profit } \\
\text { form their sale and to be reasonably } \\
\text { confident in the performance of } \\
\text { legumes as a crop. Frequently this is } \\
\text { not the case. The inability to combat } \\
\text { pests and diseases is a major reason } \\
\text { why many organic growers do not } \\
\text { produce grain legumes. }\end{array}$ & 65 & $3.90 \%$ \\
\hline Policy reforms & $\mathrm{R} \& \mathrm{D}$ & $\begin{array}{l}\text { Is it profitable for the farmer? that's } \\
\text { the question. and is the aim to } \\
\text { produce for the meat farms or } \\
\text { looking to change consumer diets to } \\
\text { more plant based. as it won't work } \\
\text { on standalone basis. long term it } \\
\text { could be positive for sustainability. } \\
\text { and improved ground conditions. } \\
\text { but farmers will need cash crops to } \\
\text { continue farming. protein crops for } \\
\text { animal feed are price driven. } \\
\text { globally. with many European } \\
\text { countries not offering the most } \\
\text { competitive advantages for a farmer } \\
\text { in the global playfield. ask the } \\
\text { question where in Europe can you } \\
\text { start a commercial farm today and } \\
\text { make a living as a farmer from } \\
\text { scratch. today this is impossible } \\
\text { investment is too high to carry. so, in } \\
\text { addition to promote these changes. } \\
\text { EU and EU countries will need to } \\
\text { review the position of the farmer. a } \\
\text { jungle of regulations will not help. }\end{array}$ & 142 & $12.70 \%$ \\
\hline Regulatory policies & R\&D & $\begin{array}{l}\text { Knew the position of the farmer. a } \\
\text { jungle of regulations will not help. }\end{array}$ & 13 & $1.20 \%$ \\
\hline System lock-ins & $\begin{array}{l}\text { Role of institutions in } \\
\text { policy change }\end{array}$ & $\begin{array}{l}\text { More and more open to change as } \\
\text { they face to technological lock-ins } \\
\text { and ask for new markets. }\end{array}$ & 18 & $1.10 \%$ \\
\hline Policy reforms & $\begin{array}{l}\text { Role of institutions in } \\
\text { policy change }\end{array}$ & $\begin{array}{l}\text { Policy direction needs to be clear if } \\
\text { the desired result is to be achieved. }\end{array}$ & 14 & $0.80 \%$ \\
\hline Policy reforms & $\begin{array}{l}\text { Role of institutions in } \\
\text { policy change }\end{array}$ & $\begin{array}{l}\text { Design better policies and inform } \\
\text { policy makers. }\end{array}$ & 8 & $0.50 \%$ \\
\hline Policy reforms & $\begin{array}{l}\text { Role of institutions in } \\
\text { policy change }\end{array}$ & $\begin{array}{c}\text { Propose initiatives and set a general } \\
\text { direction. }\end{array}$ & 7 & $0.40 \%$ \\
\hline
\end{tabular}




\begin{tabular}{|c|c|c|c|c|}
\hline Code & Case & Text & Words & $\%$ Words \\
\hline Regulatory policies & $\begin{array}{l}\text { Role of institutions in } \\
\text { policy change }\end{array}$ & $\begin{array}{l}\text { Making policy } \\
\text { decisions/regulations that promote } \\
\text { legume production and use, giving } \\
\text { dietary guidelines. }\end{array}$ & 13 & $0.80 \%$ \\
\hline Regulatory policies & $\begin{array}{l}\text { Role of institutions in } \\
\text { policy change }\end{array}$ & $\begin{array}{l}\text { Investments, regulations and public } \\
\text { support. }\end{array}$ & 5 & $0.30 \%$ \\
\hline Policy reforms & $\begin{array}{l}\text { Role of institutions in } \\
\text { policy change }\end{array}$ & $\begin{array}{l}\text { Imposition and implementation of } \\
\text { policy levers with funding. }\end{array}$ & 8 & $0.50 \%$ \\
\hline Regulatory policies & $\begin{array}{l}\text { Role of institutions in } \\
\text { policy change }\end{array}$ & Environmental legislation. & 2 & $0.10 \%$ \\
\hline Regulatory policies & $\begin{array}{l}\text { Role of institutions in } \\
\text { policy change }\end{array}$ & $\begin{array}{l}\text { Responsible for the laws and } \\
\text { regulations and their } \\
\text { implementation. }\end{array}$ & 9 & $0.50 \%$ \\
\hline Regulatory policies & $\begin{array}{l}\text { Role of institutions in } \\
\text { policy change }\end{array}$ & $\begin{array}{l}\text { Regulations, clear policy and } \\
\text { education/campaigns. }\end{array}$ & 6 & $0.40 \%$ \\
\hline Supportive & $\begin{array}{l}\text { Role of institutions in } \\
\text { policy change }\end{array}$ & $\begin{array}{l}\text { To support consumer to be able to } \\
\text { make more-sustainable food } \\
\text { consumption choices-for themselves } \\
\text { and the environment. Consumers } \\
\text { cannot remain passive recipients of } \\
\text { commercial (only) market forces. }\end{array}$ & 28 & $1.70 \%$ \\
\hline Regulatory policies & Trade policy & $\begin{array}{l}\text { More strict and really able to limit } \\
\text { the import of soy produced by } \\
\text { destroying rain forests in Amazon, } \\
\text { there could have a positive impact in } \\
\text { legume production in Europe and } \\
\text { on sustainability as well. }\end{array}$ & 34 & $2.50 \%$ \\
\hline Regulatory policies & Trade policy & $\begin{array}{l}\text { Other rules and regulations (e.g., } \\
\text { DG SAN) Also in the meat } \\
\text { consumption, the farm-to-fork } \\
\text { principle is increasing. More people } \\
\text { will be sensible for the kind of } \\
\text { animal production. }\end{array}$ & 31 & $2.30 \%$ \\
\hline
\end{tabular}

\section{Category: Technology}

\begin{tabular}{|c|c|c|c|c|}
\hline Code & Case & Text & Number of Words & $\%$ Words \\
\hline Processing & Climate measures & $\begin{array}{l}\text { There needs to be a mechanism } \\
\text { whereby small and craft-scale } \\
\text { capacities are available and } \\
\text { affordable for those small scales. } \\
\text { This is a manufacturing capacity } \\
\text { issues, and the realisation of } \\
\text { industrial engineering solutions } \\
\text { targeted specifically for the } \\
\text { small/craft scale user. }\end{array}$ & 41 & $4.30 \%$ \\
\hline
\end{tabular}

I think legumes are a good protein, energy, fibre, and mineral source. But we still lack in good products out of legumes. But where we Processing Climate measures aut of legumes. But where we 


\begin{tabular}{|c|c|c|c|c|}
\hline Code & Case & Text & Number of Words & $\%$ Words \\
\hline $\begin{array}{c}\text { Agricultural } \\
\text { extension services }\end{array}$ & $\begin{array}{c}\text { Agricultural } \\
\text { extension services }\end{array}$ & $\begin{array}{c}\text { Effective agricultural extension } \\
\text { services will likely help farmers } \\
\text { change towards more legume } \\
\text { production, }\end{array}$ & 12 & $1.40 \%$ \\
\hline Knowledge & $\begin{array}{c}\text { Agricultural } \\
\text { extension services }\end{array}$ & $\begin{array}{l}\text { Many farmers lack adequate } \\
\text { knowledge about legume } \\
\text { production since they haven't done } \\
\text { so within living memory. }\end{array}$ & 17 & $1.90 \%$ \\
\hline Knowledge & $\begin{array}{c}\text { Agricultural } \\
\text { extension services }\end{array}$ & $\begin{array}{c}\text { Many farmers simply have no clue } \\
\text { about legume production as their } \\
\text { fathers did not grow them anymore } \\
\text { and they were not taught about } \\
\text { them. }\end{array}$ & 24 & $2.70 \%$ \\
\hline Knowledge & $\begin{array}{c}\text { Agricultural } \\
\text { extension services }\end{array}$ & $\begin{array}{l}\text { There is little development work to } \\
\text { show how they can improve legume } \\
\text { crop yields on farm, so they have } \\
\text { little interest in supporting the crop. }\end{array}$ & 25 & $2.80 \%$ \\
\hline Innovation & $\begin{array}{c}\text { Agricultural } \\
\text { extension services }\end{array}$ & $\begin{array}{l}\text { Increased development work and } \\
\text { expansion of legume crops would } \\
\text { increase the interest of farm advisors } \\
\text { and lead to major improvement in } \\
\text { crop productivity, }\end{array}$ & 23 & $2.60 \%$ \\
\hline Knowledge & $\begin{array}{c}\text { Agricultural } \\
\text { extension services }\end{array}$ & $\begin{array}{l}\text { A better educated value chain and } \\
\text { more enthusiasm from advisors for } \\
\text { the benefits and use of legumes, can } \\
\text { only improve the situation. I can } \\
\text { only comment from my own } \\
\text { regional experience, and we do not } \\
\text { have a shortage of agronomists and } \\
\text { advisors, but their general level } \\
\text { engagement with legumes is low, }\end{array}$ & 51 & $5.80 \%$ \\
\hline Knowledge & $\begin{array}{c}\text { Agricultural } \\
\text { extension services }\end{array}$ & $\begin{array}{c}\text { Farmers get more information, } \\
\text { advice, and knowledge. This could } \\
\text { lead to an increased production of } \\
\text { legumes. }\end{array}$ & 16 & $1.80 \%$ \\
\hline Knowledge & $\begin{array}{l}\text { Regulating synthetic } \\
\qquad \mathrm{N} \text { use }\end{array}$ & $\begin{array}{l}\text { As regards to sustainability this } \\
\text { would substantially improve from } \\
\text { legume expansion if current } \\
\text { technical issues on legume cropping } \\
\text { would be solved. }\end{array}$ & 21 & $1.30 \%$ \\
\hline
\end{tabular}

It is critical that legumes are managed optimally to ensure that

their potential benefits are capitalised upon. It would be unfair Knowledge Regulating synthetic to push farmers towards increasing $\mathrm{N}$ use legume cropping without first

ensuring that the farmers have access to legume-agronomy training and support (including the use of cover-crops). 


\begin{tabular}{|c|c|c|c|c|}
\hline Code & Case & Text & Number of Words & $\%$ Words \\
\hline Breeding & $\begin{array}{l}\text { Regulating synthetic } \\
\text { N use }\end{array}$ & $\begin{array}{l}\text { Also, that enough crop seeds are } \\
\text { available for the growers to sow, and } \\
\text { that these are for varieties which } \\
\text { industry would like. (Note also: the } \\
\text { cover crop seed-industry in Europe } \\
\text { is not subject to the same QA } \\
\text { guarantees as cash crops such as } \\
\text { legumes, cereals etc.-in many parts } \\
\text { of Europe getting the best out of } \\
\text { legumes demands establishing a } \\
\text { good cover crop afterwards-though } \\
\text { of course they can be used as green } \\
\text { manure in their own right). }\end{array}$ & 79 & $4.80 \%$ \\
\hline Innovation & $\begin{array}{l}\text { Regulating synthetic } \\
\text { N use }\end{array}$ & $\begin{array}{l}\text { Especially if "legumes" are extended } \\
\text { to include clovers and alfalfa which } \\
\text { can be biorefined to extract food and } \\
\text { feed proteins, }\end{array}$ & 20 & $1.20 \%$ \\
\hline Knowledge & $\begin{array}{l}\text { Regulating synthetic } \\
\text { N use }\end{array}$ & $\begin{array}{c}\text { Grain legumes export a lot of } \mathrm{N} \text { in } \\
\text { the grain, forage legumes leave } \\
\text { more N. For instance, when water } \\
\text { availability is low such as in areas } \\
\text { with }<400 \mathrm{~mm} \text {, vetch as forage } \\
\text { legume or an increase in fallow can } \\
\text { occur, }\end{array}$ & 40 & $2.40 \%$ \\
\hline $\begin{array}{c}\text { Agricultural } \\
\text { extension services }\end{array}$ & $\begin{array}{l}\text { Regulating synthetic } \\
\text { N use }\end{array}$ & $\begin{array}{l}\text { This will require a lot of support } \\
\text { from agricultural research and } \\
\text { extension-services which have been } \\
\text { seriously neglected in recent } \\
\text { decades. }\end{array}$ & 22 & $1.30 \%$ \\
\hline Innovation & $\begin{array}{l}\text { Regulating synthetic } \\
\text { N use }\end{array}$ & $\begin{array}{l}\text { There will be technical improvement } \\
\text { on synthetic } \mathrm{N} \text { to reduce the } \mathrm{N} 2 \mathrm{O} \\
\text { gas emission, }\end{array}$ & 14 & $0.90 \%$ \\
\hline Research & $\begin{array}{l}\text { Regulating synthetic } \\
\text { N use }\end{array}$ & $\begin{array}{c}\text { This will require considerable R\&D } \\
\text { work into how legumes can be best } \\
\text { used in various rotations, on } \\
\text { different soil types, in different } \\
\text { climates, etc. Otherwise the effect } \\
\text { will be a general reduction in arable } \\
\text { crop productivity and sustainability. }\end{array}$ & 40 & $2.40 \%$ \\
\hline Knowledge & $\begin{array}{l}\text { Nutrition, diet, and } \\
\text { health }\end{array}$ & $\begin{array}{l}\text { To a great extent this knowledge is } \\
\text { already available but doesn't get } \\
\text { beyond expert circles. }\end{array}$ & 16 & $1.70 \%$ \\
\hline Processing & $\begin{array}{l}\text { Nutrition, diet, and } \\
\text { health }\end{array}$ & $\begin{array}{l}\text { I think we need to have some } \\
\text { convenience foods made of legumes } \\
\text { available if we truly wish to increase } \\
\text { the consumption, }\end{array}$ & 21 & $2.20 \%$ \\
\hline Knowledge & $\begin{array}{l}\text { Nutrition, diet, and } \\
\text { health }\end{array}$ & $\begin{array}{l}\text { To what extent is the capacity of } \\
\text { food literacy (i.e., home economics } \\
\text { and how to cook (legumes)) still } \\
\text { taught in schools. Food and food } \\
\text { technology education needs } \\
\text { reinvigorated across Europe. }\end{array}$ & 31 & $3.30 \%$ \\
\hline
\end{tabular}




\begin{tabular}{|c|c|c|c|c|}
\hline Code & Case & Text & Number of Words & $\%$ Words \\
\hline Knowledge & $\begin{array}{l}\text { Nutrition, diet, and } \\
\text { health }\end{array}$ & $\begin{array}{l}\text { Better informed consumption } \\
\text { choices, and the related nutrition, } \\
\text { diet and health policies, will always } \\
\text { have a significant positive impact. }\end{array}$ & 19 & $2.00 \%$ \\
\hline Knowledge & $\begin{array}{l}\text { Nutrition, diet, and } \\
\text { health }\end{array}$ & $\begin{array}{l}\text { Support consumption together with } \\
\text { a deeper education (that is: not just } \\
\text { information available but a whole } \\
\text { support-program, such as directions } \\
\text { for cooking, taste lab, taste } \\
\text { experiences, etc.), not sure how } \\
\text { much it will affect production. }\end{array}$ & 36 & $3.80 \%$ \\
\hline Research & $\begin{array}{l}\text { Nutrition, diet, and } \\
\text { health }\end{array}$ & $\begin{array}{l}\text { However, the need is to undertake } \\
\text { research to establish the } \\
\text { functionality of pulses for use by the } \\
\text { food industry as a food ingredient. }\end{array}$ & 23 & $2.40 \%$ \\
\hline Processing & $\begin{array}{l}\text { Nutrition, diet, and } \\
\text { health }\end{array}$ & $\begin{array}{l}\text { It is feasible to replace large } \\
\text { amounts of wheat and maize with } \\
\text { pulse flours as more healthy food } \\
\text { ingredients if the food processors } \\
\text { know how they can utilise them. }\end{array}$ & 29 & $3.00 \%$ \\
\hline Processing & $\begin{array}{l}\text { Nutrition, diet, and } \\
\text { health }\end{array}$ & $\begin{array}{l}\text { Alternative foods must be promoted. } \\
\text { Primarily however they must be } \\
\text { tasty and attractively priced, i.e } \\
\text { desirable. This largely means } \\
\text { improvements in processed foods } \\
\text { with legumes as increasing } \\
\text { proportion of the ingredients and a } \\
\text { price that moves peoples' attention } \\
\text { away from animal protein sources. }\end{array}$ & 43 & $4.50 \%$ \\
\hline Processing & R\&D & $\begin{array}{l}\text { Improved processing for feed and } \\
\text { food the demand may also be } \\
\text { growing, }\end{array}$ & 12 & $1.10 \%$ \\
\hline Breeding & R\&D & $\begin{array}{l}\text { It is also important that the new } \\
\text { types are also bred to optimise } \\
\text { system functions, }\end{array}$ & 14 & $1.30 \%$ \\
\hline Breeding & R\&D & $\begin{array}{l}\text { New cultivars resistant to diseases } \\
\text { (Conventional and genetic editing) } \\
\text { and new cropping systems can } \\
\text { facilitate introduction of (grain) } \\
\text { legumes in rotations because } \\
\text { farmers will have an easier task, }\end{array}$ & 28 & $2.50 \%$ \\
\hline Breeding & R\&D & Are focused on new breeds, & 5 & $0.40 \%$ \\
\hline Processing & R\&D & $\begin{array}{l}\text { Novel options for the storage and } \\
\text { processing of legumes will have } \\
\text { some positive impact, }\end{array}$ & 14 & $1.30 \%$ \\
\hline Knowledge & R\&D & $\begin{array}{c}\text { However, require more than } \\
\text { increased knowledge, }\end{array}$ & 6 & $0.50 \%$ \\
\hline Innovation & R\&D & $\begin{array}{l}\text { Development of new products by } \\
\text { the aggrotech industry not currently } \\
\text { justified, }\end{array}$ & 12 & $1.10 \%$ \\
\hline
\end{tabular}




\begin{tabular}{|c|c|c|c|c|}
\hline Code & Case & Text & Number of Words & $\%$ Words \\
\hline Research & R\&D & $\begin{array}{l}\text { Legume research will only be } \\
\text { playing catch up in this respect and } \\
\text { will need very considerably more } \\
\text { input to make rapid progress, }\end{array}$ & 22 & $2.00 \%$ \\
\hline Breeding & $R \& D$ & $\begin{array}{l}\text { Progression of varieties is the } \\
\text { natural territory of the breeder BUT } \\
\text { they are limited in their interests (as } \\
\text { is the rest of the value chain) by the } \\
\text { size of the market. Production of } \\
\text { more is possible using the varieties } \\
\text { that already exist. Regional } \\
\text { production of species that are not } \\
\text { already produced is one potential } \\
\text { area that could benefit e.g., } \\
\text { chickpeas and lentil in NW Europe, } \\
\text { though in reality there is probably } \\
\text { material in existence that can } \\
\text { already be made to work in many } \\
\text { situations IF growers see an } \\
\text { opportunity to profit and are } \\
\text { prepared to experiment, learn and } \\
\text { accept some variability in } \\
\text { performance year on year. }\end{array}$ & 108 & $9.70 \%$ \\
\hline Breeding & R\&D & $\begin{array}{l}\text { New breeds are urgently needed for } \\
\text { climate adaptation. }\end{array}$ & 8 & $0.70 \%$ \\
\hline Innovation & $\begin{array}{l}\text { Role of institutions in } \\
\text { policy change }\end{array}$ & $\begin{array}{l}\text { Innovations in plant-based } \\
\text { substitutes. }\end{array}$ & 5 & $0.30 \%$ \\
\hline Knowledge & $\begin{array}{l}\text { Role of institutions in } \\
\text { policy change }\end{array}$ & $\begin{array}{l}\text { It could be fact-based instead of } \\
\text { opinion-biased. }\end{array}$ & 8 & $0.50 \%$ \\
\hline Breeding & $\begin{array}{l}\text { Role of institutions in } \\
\text { policy change }\end{array}$ & Breeding. & 1 & $0.10 \%$ \\
\hline Processing & $\begin{array}{l}\text { Role of institutions in } \\
\text { policy change }\end{array}$ & Processing legumes. & 2 & $0.10 \%$ \\
\hline Breeding & $\begin{array}{l}\text { Role of institutions in } \\
\text { policy change }\end{array}$ & $\begin{array}{l}\text { Breeding of legumes with higher } \\
\text { production and higher resistance } \\
\text { towards pests and diseases. }\end{array}$ & 13 & $0.80 \%$ \\
\hline Innovation & $\begin{array}{l}\text { Role of institutions in } \\
\text { policy change }\end{array}$ & $\begin{array}{c}\text { Entrepreneurs to develop novel food } \\
\text { types. Food entrepreneurs to } \\
\text { develop novel recipes containing } \\
\text { legumes. }\end{array}$ & 14 & $0.80 \%$ \\
\hline Processing & $\begin{array}{l}\text { Role of institutions in } \\
\text { policy change }\end{array}$ & $\begin{array}{l}\text { To explore or expand use of legumes } \\
\text { in flour. }\end{array}$ & 9 & $0.50 \%$ \\
\hline Innovation & $\begin{array}{l}\text { Role of institutions in } \\
\text { policy change }\end{array}$ & Innovative products. & 2 & $0.10 \%$ \\
\hline Innovation & $\begin{array}{l}\text { Role of institutions in } \\
\text { policy change }\end{array}$ & $\begin{array}{l}\text { Stainable and future-oriented } \\
\text { technologies, innovations, goods } \\
\text { and services. }\end{array}$ & 9 & $0.50 \%$ \\
\hline Innovation & $\begin{array}{l}\text { Role of institutions in } \\
\text { policy change }\end{array}$ & $\begin{array}{l}\text { Palatability of leguminous products } \\
\text { through the use of innovative food } \\
\text { processing technologies }\end{array}$ & 12 & $0.70 \%$ \\
\hline
\end{tabular}




\begin{tabular}{|c|c|c|c|c|}
\hline Code & Case & Text & Number of Words & $\%$ Words \\
\hline Processing & $\begin{array}{l}\text { Role of institutions in } \\
\text { policy change }\end{array}$ & $\begin{array}{l}\text { Food industry new product } \\
\text { development to seek ways of } \\
\text { improving food nutritional value by } \\
\text { using pulses and pulse products as } \\
\text { food ingredients. }\end{array}$ & 22 & $1.30 \%$ \\
\hline Innovation & $\begin{array}{l}\text { Role of institutions in } \\
\text { policy change }\end{array}$ & Put policy into practice.. & 5 & $0.30 \%$ \\
\hline Research & $\begin{array}{l}\text { Role of institutions in } \\
\text { policy change }\end{array}$ & $\begin{array}{l}\text { Research, extension innovations to } \\
\text { support farmer capacity. }\end{array}$ & 7 & $0.40 \%$ \\
\hline Knowledge & $\begin{array}{l}\text { Role of institutions in } \\
\text { policy change }\end{array}$ & $\begin{array}{l}\text { Inform about options or scenarios, } \\
\text { their conditions, and effects on and } \\
\text { beyond agriculture based on best } \\
\text { scientific evaluation. }\end{array}$ & 18 & $1.10 \%$ \\
\hline Knowledge & $\begin{array}{l}\text { Role of institutions in } \\
\text { policy change }\end{array}$ & $\begin{array}{l}\text { Unbiased KNOWLEDGE to the } \\
\text { policy. }\end{array}$ & 5 & $0.30 \%$ \\
\hline Knowledge & $\begin{array}{l}\text { Role of institutions in } \\
\text { policy change }\end{array}$ & $\begin{array}{c}\text { Knowledge regarding legumes as } \\
\text { part of crop rotation. }\end{array}$ & 8 & $0.50 \%$ \\
\hline Research & $\begin{array}{l}\text { Role of institutions in } \\
\text { policy change }\end{array}$ & $\begin{array}{l}\text { Research into agro-food } \\
\text { technologies. }\end{array}$ & 5 & $0.30 \%$ \\
\hline Breeding & $\begin{array}{l}\text { Role of institutions in } \\
\text { policy change }\end{array}$ & $\begin{array}{l}\text { Legume breeding and the } \\
\text { improvement of cropping systems. }\end{array}$ & 9 & $0.50 \%$ \\
\hline $\begin{array}{l}\text { Agricultural } \\
\text { extension services }\end{array}$ & $\begin{array}{l}\text { Role of institutions in } \\
\text { policy change }\end{array}$ & $\begin{array}{l}\text { Providing with technical advice and } \\
\text { incentives to the producers. }\end{array}$ & 9 & $0.50 \%$ \\
\hline Knowledge & $\begin{array}{l}\text { Role of institutions in } \\
\text { policy change }\end{array}$ & $\begin{array}{l}\text { Generating knowledge and } \\
\text { teaching. }\end{array}$ & 4 & $0.20 \%$ \\
\hline Research & $\begin{array}{l}\text { Role of institutions in } \\
\text { policy change }\end{array}$ & $\begin{array}{l}\text { R\&D funds to support improved } \\
\text { legume crop productivity and use as } \\
\text { food ingredients. }\end{array}$ & 13 & $0.80 \%$ \\
\hline Research & $\begin{array}{l}\text { Role of institutions in } \\
\text { policy change }\end{array}$ & $\begin{array}{l}\text { Breeding or subsidised breeding and } \\
\text { production research is essential as } \\
\text { legumes start at a comparative } \\
\text { disadvantage after years of under } \\
\text { investment by industry. These } \\
\text { investments are not necessarily endless } \\
\text { but essentially filling a gap where in } \\
\text { this case the market has failed. }\end{array}$ & 43 & $2.60 \%$ \\
\hline Breeding & $\begin{array}{l}\text { Role of institutions in } \\
\text { policy change }\end{array}$ & $\begin{array}{l}\text { Breeding or subsidised breeding and } \\
\text { production research is essential as } \\
\text { legumes start at a comparative } \\
\text { disadvantage after years of under } \\
\text { investment by industry. These } \\
\text { investments are not necessarily endless } \\
\text { but essentially filling a gap where in } \\
\text { this case the market has failed. }\end{array}$ & 43 & $2.60 \%$ \\
\hline Knowledge & $\begin{array}{l}\text { Role of institutions in } \\
\text { policy change }\end{array}$ & $\begin{array}{l}\text { To support consumer to be able to } \\
\text { make more-sustainable food } \\
\text { consumption choices-for themselves } \\
\text { and the environment. Consumers } \\
\text { cannot remain passive recipients of } \\
\text { commercial (only) market forces. }\end{array}$ & 28 & $1.70 \%$ \\
\hline
\end{tabular}




\begin{tabular}{ccccc}
\hline Code & Case & Text & Number of Words & \% Words \\
\hline Knowledge & $\begin{array}{c}\text { Role of institutions in } \\
\text { policy change }\end{array}$ & $\begin{array}{c}\text { Farmer knowledge exchange, } \\
\text { cooperative business models. }\end{array}$ & 6 & $0.40 \%$ \\
\hline Innovation & Trade policy & $\begin{array}{c}\text { Innovative products and processing } \\
\text { methods. }\end{array}$ & 5 & $0.40 \%$ \\
\hline
\end{tabular}

Category: Farming

\begin{tabular}{|c|c|c|c|c|}
\hline Code & Case & Text & Words & $\%$ Words \\
\hline $\begin{array}{l}\text { Smallholder/small } \\
\text { scale }\end{array}$ & Climate measures & $\begin{array}{l}\text { Animals are an important part of } \\
\text { mixed farming systems and fulfil an } \\
\text { important traditional and cultural part } \\
\text { for many smallholders. }\end{array}$ & 20 & $2.10 \%$ \\
\hline
\end{tabular}

It is also not realistic either, so I am not

in favour of this. We need to consider

the whole food system and also

population health, how to best fit

Nutrition Climate measures animal production to plant production

$6.00 \%$

and also take into account non-food

side-streams that be utilised in animal

husbandry to produce high-value protein for humans.

Decreasing the consumption of red

meat from the current level may do us

good but whole nations to move to

Nutrition Climate measures vegan diets may expose to some

$4.20 \%$

serious health risks, particularly in

vulnerable groups such as growing children and aged people.

Be careful with the huge increase of biomass production and the requirement to find and to develop

Production Climate measures new end uses (non-food?). 80\% of the land is used to feed animals today, so the livestock reduction will offer the opportunity to grow something else: the question is what.

\begin{tabular}{|c|c|c|c|c|}
\hline Production & $\begin{array}{c}\text { Agricultural } \\
\text { extension services }\end{array}$ & $\begin{array}{c}\text { Transforming EU agriculture; therefore, } \\
\text { they would result in improving legume } \\
\text { production and agriculture } \\
\text { sustainability. }\end{array}$ & 14 & $1.60 \%$ \\
\hline Production & $\begin{array}{c}\text { Agricultural } \\
\text { extension services }\end{array}$ & $\begin{array}{l}\text { Focuses on the production part, not the } \\
\text { consumption. }\end{array}$ & 8 & $0.90 \%$ \\
\hline Meat/dairy & $\begin{array}{l}\text { Agricultural } \\
\text { extension services }\end{array}$ & Meat producers. & 4 & $0.50 \%$ \\
\hline $\begin{array}{l}\text { Good agricultural } \\
\text { practices }\end{array}$ & $\begin{array}{c}\text { Agricultural } \\
\text { extension services }\end{array}$ & $\begin{array}{l}\text { Farmers thanks to good practices and } \\
\text { high-quality products. }\end{array}$ & 9 & $1.00 \%$ \\
\hline Rotations & $\begin{array}{c}\text { Agricultural } \\
\text { extension services }\end{array}$ & $\begin{array}{l}\text { rotations and the production of } \\
\text { legumes. }\end{array}$ & 8 & $0.90 \%$ \\
\hline Crops/arable area & $\begin{array}{l}\text { Agricultural } \\
\text { extension services }\end{array}$ & $\begin{array}{c}\text { As a crop area of just } 3-4 \% \text { is inevitably } \\
\text { going to attract a similar proportion of } \\
\text { the interest. }\end{array}$ & 19 & $2.20 \%$ \\
\hline
\end{tabular}




\begin{tabular}{|c|c|c|c|c|}
\hline Code & Case & Text & Words & $\%$ Words \\
\hline $\begin{array}{l}\text { Smallholder/small } \\
\text { scale }\end{array}$ & $\begin{array}{c}\text { Agricultural } \\
\text { extension services }\end{array}$ & $\begin{array}{l}\text { If all farmers would have a profit from } \\
\text { that or if again the small family farms } \\
\text { become forgotten. }\end{array}$ & 18 & $2.10 \%$ \\
\hline Rotations & $\begin{array}{l}\text { Regulating synthetic } \\
\mathrm{N} \text { use }\end{array}$ & $\begin{array}{c}\text { One might see a change in crop } \\
\text { rotations. }\end{array}$ & 8 & $0.50 \%$ \\
\hline Production & $\begin{array}{l}\text { Regulating synthetic } \\
\text { N use }\end{array}$ & $\begin{array}{l}\text { Clearly a policy restricting the use of } \\
\text { synthetic } N \text { fertilisers would be } \\
\text { favourable for legumes production. }\end{array}$ & 16 & $1.00 \%$ \\
\hline Rotations & $\begin{array}{l}\text { Regulating synthetic } \\
\mathrm{N} \text { use }\end{array}$ & $\begin{array}{l}\text { Would need quite a lot of work to } \\
\text { optimise crop rotation etc.. }\end{array}$ & 13 & $0.80 \%$ \\
\hline Rotations & $\begin{array}{l}\text { Regulating synthetic } \\
\text { N use }\end{array}$ & $\begin{array}{l}\text { The limitation on } \mathrm{N} \text { use can affect } \\
\text { rotation sequences and legumes can be } \\
\text { included more frequently in new } \\
\text { rotations. What legume is introduced is } \\
\text { another question. }\end{array}$ & 26 & $1.60 \%$ \\
\hline Production & $\begin{array}{l}\text { Regulating synthetic } \\
\text { N use }\end{array}$ & $\begin{array}{l}\text { I think effect on production is different } \\
\text { than effect on consumption. If there } \\
\text { were to be measures to restrict the } \\
\text { application of synthetic } \mathrm{N} \text { fertilizer, } \\
\text { legume production would certainly } \\
\text { increase. }\end{array}$ & 30 & $1.80 \%$ \\
\hline Rotations & $\begin{array}{l}\text { Regulating synthetic } \\
\qquad \mathrm{N} \text { use }\end{array}$ & $\begin{array}{l}\text { As regards the implications for the } \\
\text { sustainability of EU agriculture, clearly } \\
\text { the potential expansion of legumes } \\
\text { needs to be part of a new crop rotation } \\
\text { regime in which beans \& pulses } \\
\text { co-exist with grains, roots, and tubers. }\end{array}$ & 37 & $2.20 \%$ \\
\hline Rotations & $\begin{array}{l}\text { Regulating synthetic } \\
\text { N use }\end{array}$ & $\begin{array}{l}\text { Any restriction in use of } \mathrm{N} \text { will } \\
\text { certainly lead to a modification of the } \\
\text { cropping systems. Rotations will be } \\
\text { adapted to include } \mathrm{N} \text {-fixing crops. }\end{array}$ & 25 & $1.50 \%$ \\
\hline Production & $\begin{array}{l}\text { Regulating synthetic } \\
\text { N use }\end{array}$ & $\begin{array}{l}\text { Restrictions on synthetic } \mathrm{N} \text { use will } \\
\text { have a negative impact on crop } \\
\text { productivity. }\end{array}$ & 13 & $0.80 \%$ \\
\hline Rotations & $\begin{array}{l}\text { Regulating synthetic } \\
\qquad \mathrm{N} \text { use }\end{array}$ & $\begin{array}{l}\text { To counter this the need will be to } \\
\text { create a different balance in the } \\
\text { rotations which are likely to lead to the } \\
\text { use of more legume crops. }\end{array}$ & 27 & $1.60 \%$ \\
\hline Production & $\begin{array}{l}\text { Regulating synthetic } \\
\qquad \mathrm{N} \text { use }\end{array}$ & $\begin{array}{l}\text { Increased availability will increase } \\
\text { consumption in the animal feed sector, } \\
\text { perhaps at the expense of imported } \\
\text { soya, BUT this sector may also decline } \\
\text { if the costs of production rise and meat } \\
\text { consumption is to be discouraged with } \\
\text { higher prices and negative } \\
\text { environmental messages. Consistency } \\
\text { of availability of product is an } \\
\text { often-declared reason for the current } \\
\text { low level of use, therefore more } \\
\text { availability would potentially drive } \\
\text { consumption. }\end{array}$ & 67 & $4.10 \%$ \\
\hline
\end{tabular}




\begin{tabular}{|c|c|c|c|c|}
\hline Code & Case & Text & Words & $\%$ Words \\
\hline Rotations & $\begin{array}{l}\text { Regulating synthetic } \\
\text { N use }\end{array}$ & $\begin{array}{c}\text { Shortage of synthetic } \mathrm{N} \text { will stimulate } \\
\text { the use of legumes in rotation and } \\
\text { reduce the opportunities for high } \\
\text { protein feed. }\end{array}$ & 20 & $1.20 \%$ \\
\hline Nutrition & $\begin{array}{l}\text { Nutrition, diet, and } \\
\text { health }\end{array}$ & $\begin{array}{l}\text { I could imagine that people eat more } \\
\text { legumes if they know more about } \\
\text { nutrition but if that will significantly } \\
\text { change production patterns, I do not } \\
\text { know. }\end{array}$ & 26 & $2.70 \%$ \\
\hline Pest resistance & R\&D & $\begin{array}{l}\text { If the R\&D makes legume yield less } \\
\text { dependent on the vagaries of weather } \\
\text { and pests, I think farmers would be } \\
\text { happy to include legumes in their crop } \\
\text { rotations. }\end{array}$ & 29 & $2.60 \%$ \\
\hline Rotations & R\&D & $\begin{array}{l}\text { The only one of these measures to } \\
\text { affect legume production is the crop } \\
\text { rotation schemes. }\end{array}$ & 15 & $1.30 \%$ \\
\hline Production & R\&D & $\begin{array}{l}\text { Technical shortcomings of legume } \\
\text { production, this would substantially } \\
\text { improve their production and } \\
\text { sustainability in EU agriculture. }\end{array}$ & 16 & $1.40 \%$ \\
\hline Pest resistance & R\&D & $\begin{array}{l}\text { New cultivars resistant to diseases } \\
\text { (Conventional and genetic editing) and } \\
\text { new cropping systems can facilitate } \\
\text { introduction of (grain) legumes in } \\
\text { rotations because farmers will have an } \\
\text { easier task. }\end{array}$ & 28 & $2.50 \%$ \\
\hline Rotations & R\&D & $\begin{array}{l}\text { Effective crop rotation schemes, new } \\
\text { strategies to better recycle N. }\end{array}$ & 10 & $0.90 \%$ \\
\hline Pest resistance & Trade policy & $\begin{array}{l}\text { They have too many problems with } \\
\text { diseases, weeds, and pests. }\end{array}$ & 10 & $0.70 \%$ \\
\hline Meat/dairy & Trade policy & $\begin{array}{l}\text { Production of which I think have to be } \\
\text { substantially reduced in line with } \\
\text { EAT-Lancet proposals to cut meat } \\
\text { consumption by half. Cheap soy meal } \\
\text { from Brazil \& elsewhere in S. America } \\
\text { has to be eliminated in the interests of } \\
\text { ecological restoration. }\end{array}$ & 41 & $3.00 \%$ \\
\hline
\end{tabular}

\section{Appendix C. Components of the Seven Policy Scenarios}

Table A1 shows the frequency of keywords (codes) present in the participants' comments for the seven proposed scenarios. It was perceived that abandonment of the CAP would have a strong negative impact on the competitiveness and sustainability of EU agriculture. Though there was an acknowledgement that further CAP reform might be necessary, respondents advised that the CAP should not be eliminated. 
Table A1. Frequencies (\%) of keywords (codes) mentioned in the participants' comments in relation to the seven policy scenarios described in Table 2. Absence of data refers to frequencies $<4 \%$.

\begin{tabular}{|c|c|c|c|c|c|c|c|}
\hline Keywords & $\begin{array}{l}\text { Climate } \\
\text { Measures }\end{array}$ & N Fertilizer & $\begin{array}{c}\text { Elimination } \\
\text { of CAP }\end{array}$ & $\begin{array}{l}\text { Extension } \\
\text { Services }\end{array}$ & $\begin{array}{c}\text { Nutrition, } \\
\text { Diet, and } \\
\text { Health }\end{array}$ & R\&D & Trade Policy \\
\hline \multicolumn{8}{|c|}{$\%$ of Words } \\
\hline Breeding & & 4.8 & & & & 14.4 & \\
\hline Climate change & & & 5.5 & & & & \\
\hline Consumption & & 6.5 & & & & & \\
\hline Competition & & & 15 & & & & \\
\hline Complexity & & & 4 & & 4 & & \\
\hline Costs & & & 11 & & & & \\
\hline Externalities & & & 5 & & & & \\
\hline Fertilizers & 4.5 & & & & & & \\
\hline Health & & & & & 6 & & \\
\hline Inertia & 4.1 & & & & & & \\
\hline Incentives & & & & 6 & & & \\
\hline Investment & & & & & 4.8 & 4.1 & \\
\hline Knowledge & & 6.5 & & 15 & 10.5 & & \\
\hline Nutrition & 11 & & & & & & \\
\hline Pest resistance & & & & & & 4.5 & \\
\hline Policy reforms & & & 13.8 & 6.5 & & 12.6 & 4.5 \\
\hline Preferences & & & & & 11 & & \\
\hline Production & 4.3 & 7.5 & & & & & \\
\hline Processing & 8.5 & & & & 9.8 & & \\
\hline Rotations & & 9.5 & & & & & \\
\hline Subsidies & & & 4 & & & & \\
\hline System lock-ins & & & & 4.3 & & & \\
\hline Sustainability & 22 & 4.4 & 14.5 & 4.2 & & & \\
\hline Trade & & & & & & & 5.5 \\
\hline Tradition & & & & & 8.2 & & \\
\hline
\end{tabular}

\section{References}

1. Jensen, E.S.; Peoples, M.B.; Boddey, R.M.; Gresshoff, P.M.; Hauggaard-Nielsen, H.; Alves, B.J.R.; Morrison, M.J. Legumes for mitigation of climate change and the provision of feedstock for biofuels and biorefineries. A review. Agron. Sustain. Dev. 2012, 32, 329-364. [CrossRef]

2. Dequiedt, B.; Moran, D. The cost of emission mitigation by legume crops in French agriculture. Ecol. Econ. 2015, 110, 51-60. [CrossRef]

3. Balázs, B.; Kelemen, E.; Debeljak, M.; Hamann, K.; Kolmans, A.; Maaß, H.; Vasconcelos, M.; Williams, M.; Squire, G.; Iannetta, P. Report on Co-Design of Policy Analysis. Deliverable 7.1 for the EU-H2020 Funded Project, 'Transition Paths to Sustainable Legume-Based Systems in Europe' (TRUE). 2018. Available online: www.true-project.eu (accessed on 17 December 2020).

4. Magrini, M.-B.; Anton, M.; Cholez, C.; Corre-Hellou, G.; Duc, G.; Jeuffroy, M.-H.; Meynard, J.-M.; Pelzer, E.; Voisin, A.-S.; Walrand, S. Why are grain-legumes rarely present in cropping systems despite their environmental and nutritional benefits? Analyzing lock-in in the French agrifood system. Ecol. Econ. 2016, 126, 152-162. [CrossRef]

5. Zander, P.; Amjath-Babu, T.S.; Preissel, S.; Reckling, M.; Bues, A.; Schläfke, N.; Kuhlman, T.; Bachinger, J.; Uthes, S.; Stoddard, F.; et al. Grain legume decline and potential recovery in European agriculture: A review. Agron. Sustain. Dev. 2016, 36, 26. [CrossRef]

6. Annicchiarico, P. Feed legumes for truly sustainable crop-animal systems. Ital. J. Agron. 2017, 12. [CrossRef]

7. Helming, J.F.M.; Kuhlman, T.; Linderhof, V.; Oudendag, D. Impacts of Legume-Related Policy Scenarios; Legume Futures Report 4.5; LEI Wageningen UR: The Hague, The Netherlands, 2014.

8. Topp, K.; Watson, C.; Papa, V.; Williams, M.; Stout, J.; Cass, S.; Fischer, J.; Böhm, H.; Murphy-Bokern, D.; Kuhlman, T.; et al. Policy Implications of the Environmental and Resource Effects of Legume Cropping. Legume Futures Report 3.8/6.6. Available online: http:/ / www.legumefutures.de/images/Legume_Futures_Report_3.8-6.6.docx (accessed on 26 March 2021).

9. Recanati, F.; Maughan, C.; Pedrotti, M.; Dembska, K.; Antonelli, M. Assessing the role of CAP for more sustainable and healthier food systems in Europe: A literature review. Sci. Total Environ. 2019, 653, 908-919. [CrossRef] [PubMed]

10. SWD (2016) 218 Final of 22.6.2016. Available online: https:/ / ec.europa.eu/transparency/regdoc/rep/10102/2016/EN/SWD-20 16-218-F1-EN-MAIN-PART-2.PDF (accessed on 26 March 2021). 
11. EC Report from The Commission to the Council and the European Parliament on the Development of Plant Proteins in the European Union. Brussels. 2018. Available online: https:// eur-lex.europa.eu/legal-content/EN/TXT/?uri=CELEX\%3A52018 DC0757 (accessed on 17 December 2020).

12. EC Farm to Fork Strategy for a Fair, Healthy and Environmentally-Friendly Food System. Available online: https://ec.europa. eu/food/farm2fork_en (accessed on 26 March 2021).

13. De Schutter, O. Report Submitted by the Special Rapporteur on the Right to Food. 2010. Available online: https://www2.ohchr. org/english/issues/food/docs/A-HRC-16-49.pdf (accessed on 17 December 2020).

14. Gomez, A.A.; Kelly, D.E.S.; Syers, J.K.; Coughlan, K.J. Measuring Sustainability of Agricultural Systems at the Farm Level. In Methods for Assessing Soil Quality; John Wiley \& Sons, Ltd.: Hoboken, NJ, USA, 1997; pp. 401-410. ISBN 978-0-89118-944-2.

15. De Loe, R.C. Exploring complex policy questions using the policy Delphi: A multi-round, interactive survey method. Appl. Geogr. 1995, 15, 53-68. [CrossRef]

16. Rayens, M.K.; Hahn, E.J. Building Consensus Using the Policy Delphi Method. Policy Polit. Nurs. Pract. 2000, 1, 308-315. [CrossRef]

17. Strategic Foresight for Better Policies: Building Effective Governance in the Face of Uncertain Futures. 2009. Available online: https: / / www.oecd.org/strategic-foresight/ourwork/Strategic\%20Foresight\%20for\%20Better\%20Policies.pdf (accessed on 17 December 2020).

18. Frewer, L.J.; Fischer, A.R.H.; Wentholt, M.T.A.; Marvin, H.J.P.; Ooms, B.W.; Coles, D.; Rowe, G. The use of Delphi methodology in agrifood policy development: Some lessons learned. Technol. Forecast. Soc. Chang. 2011, 78, 1514-1525. [CrossRef]

19. Hebinck, A.; Vervoort, J.; Hebinck, P.; Rutting, L.; Galli, F. Imagining transformative futures: Participatory foresight for food systems change. Ecol. Soc. 2018, 23. [CrossRef]

20. Mangnus, A.; Vervoort, J.; McGreevy, S.; Ota, K.; Rupprecht, C.; Oga, M.; Kobayashi, M. New pathways for governing food system transformations: A pluralistic practice-based futures approach using visioning, back-casting, and serious gaming. Ecol. Soc. 2019, 24. [CrossRef]

21. Szakál, D.; Balázs, B. Co-creation for transformation: Food for degrowth in Budapest Food City Lab initiatives. In Food for Degrowth; Routledge: London, UK, 2020; ISBN 978-1-00-300482-0.

22. Popper, R. Foresight methodology. In The Handbook of Technology Foresight; MPG Books Ltd.: Bodmin, UK, 2008 ; pp. 44-88.

23. Aligica, P.D.; Herritt, R. Epistemology, social technology, and expert judgement: Olaf Helmer's contribution to futures research. Futures 2009, 41, 253-259. [CrossRef]

24. Dalkey, N.; Helmer, O. An Experimental Application of the DELPHI Method to the Use of Experts. Manag. Sci. 1963, 9, 458-467. [CrossRef]

25. Helmer, O. Problems in futures research: Delphi and causal cross-impact analysis. Futures 1977, 9, 17-31. [CrossRef]

26. Rikkonen, P.; Aakkula, J.; Kaivo-oja, J. How can future long-term changes in finnish agriculture and agricultural policy be faced? defining strategic agendas on the basis of a delphi study. Eur. Plan. Stud. 2006, 14, 147-168. [CrossRef]

27. Bolger, F.; Wright, G. Improving the Delphi process: Lessons from social psychological research. Technol. Forecast. Soc. Chang. 2011, 78, 1500-1513. [CrossRef]

28. Kuusi, O. Expertise in the Future Use of Generic Technologies. Epistemic and Methodological Considerations Concerning Delphi Studies; Valtion Taloudellinen Tutkimuskeskus VATT: Helsinki, Finland, 1999.

29. Balázs, B.; Kelemen, E.; Centofanti, T.; Vasconcelos, M.; Maaß, H.; Kolmans, A.; Squire, G.; Tran, F.; Bienkowski, D.; Iannetta, P. Application of Delphi for governance contexts which favour legume-supported value chains. TRUE Proj. 2019. [CrossRef]

30. Tapio, P. Disaggregative policy Delphi. Technol. Forecast. Soc. Chang. 2003, 70, 83-101. [CrossRef]

31. Landeta, J.; Barrutia, J.; Lertxundi, A. Hybrid Delphi: A methodology to facilitate contribution from experts in professional contexts. Technol. Forecast. Soc. Chang. 2011, 78, 1629-1641. [CrossRef]

32. Balázs, B.; Kelemen, E.; Centofanti, T.; Vasconcelos, M.; Iannetta, P.P.M. TRUE Policy Delphi First and Second Round Results (Data and Figures in pdf) 2020. Available online: https:/ / zenodo.org/record/4817334\#.YOUHE0y-uUk (accessed on 26 March 2021).

33. Balázs, B.; Kelemen, E.; Centofanti, T.; Vasconcelos, M.W.; Iannetta, P.P.M. Integrated policy analysis to identify transformation paths to more sustainable legume-based food and feed value-chains in Europe. Agroecol. Sustain. Food Syst. 2021, 45, 931-953. [CrossRef]

34. Baiocchi, G.; Distaso, W. GRETL: Econometric Software for the GNU Generation. J. Appl. Econom. 2003, 18, 105-110. [CrossRef]

35. Mahesh, R.; Vandevijvere, S.; Dominick, C.; Swinburn, B. Relative contributions of recommended food environment policies to improve population nutrition: Results from a Delphi study with international food policy experts. Public Health Nutr. 2018, 21, 2142-2148. [CrossRef] [PubMed]

36. Tiberius, V.; Borning, J.; Seeler, S. Setting the table for meat consumers: An international Delphi study on in vitro meat. NPJ Sci. Food 2019, 3, 10. [CrossRef] [PubMed]

37. Antonelli, M.; Basile, L.; Gagliardi, F.; Isernia, P. The AGRIFOODMED Delphi-Trends, Challenges and Policy Options for Water Management, Farming Systems and Agri-Food Value Chains in 2020-2030. PRIMA Annual Work Plan 2018.2019. Available online: https://www.researchgate.net/publication/333872330_2019_AGRIFOODMED_DELPHI_Trends_challenges_ and_policy_options_for_Water_Management_Farming_Systems_and_Agri-food_Value_Chains_in_2020-2030 (accessed on 17 December 2020). 
38. Su, J.Y.; Canavari, M. Delphi study on country-of-origin labelling for processed foods. Agric. Food Econ. 2018, 6, 8. [CrossRef]

39. Moragues-Faus, A.; Sonnino, R.; Marsden, T. Exploring European food system vulnerabilities: Towards integrated food security governance. Environ. Sci. Policy 2017, 75, 184-215. [CrossRef]

40. Allen, T.; Prosperi, P.; Cogill, B.; Padilla, M.; Peri, I. A Delphi Approach to Develop Sustainable Food System Metrics. Soc. Indic. Res. 2019, 141. [CrossRef]

41. Boylan, S.; Sainsbury, E.; Thow, A.-M.; Degeling, C.; Craven, L.; Stellmach, D.; Gill, T.; Zhang, Y. A healthy, sustainable and safe food system: Examining the perceptions and role of the Australian policy actor using a Delphi survey. Public Health Nutr. 2019, 22, 1-10. [CrossRef]

42. Haynes, E.; Palermo, C.; Reidlinger, D. Modified Policy-Delphi study for exploring obesity prevention priorities. BMJ Open 2016, 6, e011788. [CrossRef]

43. Hung, Y.; Hieke, S.; Grunert, K.G.; Verbeke, W. Setting Policy Priorities for Front-of-Pack Health Claims and Symbols in the European Union: Expert Consensus Built by Using a Delphi Method. Nutrients 2019, 11, 403. [CrossRef] [PubMed]

44. Squire, G.R.; Quesada, N.; Begg, G.S.; Iannetta, P.P.M. Transitions to greater legume inclusion in cropland: Defining opportunities and estimating benefits for the nitrogen economy. Food Energy Secur. 2019, 8, e00175. [CrossRef]

45. Clark, W.; Lenaghan, M. The Future of Food: Sustainable Protein Strategies around the World; Zero Waste Scotland: Scotland, UK, 2020.

46. Costa, M.P.; Chadwick, D.; Saget, S.; Rees, R.M.; Williams, M.; Styles, D. Representing crop rotations in life cycle assessment: A review of legume LCA studies. Int. J. Life Cycle Assess. 2020, 25, 1942-1956. [CrossRef]

47. Martineau, H.; Wiltshire, J.; Webb, J.; Hart, K.; Keenleyside, C.; Baldock, D.; Bell, H.; Watterson, J. Effective Performance of Tools for Climate Action Policy. Meta-Review of Common Agricultural Policy (CAP) Mainstreaming. Report for European Commission-DG. Climate Action; Ricardo-AEA Ltd.: Glasgow, UK, 2016.

48. Śmiglak-Krajewska, M.; Wojciechowska-Solis, J.; Viti, D. Consumers' Purchasing Intentions on the Legume Market as Evidence of Sustainable Behaviour. Agriculture 2020, 10, 424. [CrossRef]

49. Tziva, M.; Negro, S.O.; Kalfagianni, A.; Hekkert, M.P. Understanding the protein transition: The rise of plant-based meat substitutes. Environ. Innov. Soc. Transit. 2020, 35, 217-231. [CrossRef] 